\title{
Tradescantia Bioassays as Monitoring Systems for Environmental Mutagenesis: A Review
}

\author{
Geraldo Stachetti Rodrigues, ${ }^{1}$ Te-Hsiu Ma, ${ }^{2}$ David Pimentel, ${ }^{3}$ and \\ Leonard $H$. Weinstein ${ }^{3,4}$
}

'Embrapa/CNPMA - Centro Nacional de Pesquisa de Monitoramento e Avaliação de Impacto Ambiental, Caixa Postal 069, Jaguariúna, São Paulo, CEP 13820, Brazil; 'Western Illinois University, Macomb, IL, 61455; ${ }^{3}$ Cornell University, Ithaca, NY, 14853; ${ }^{4}$ Boyce Thompson Institute for Plant Research, Ithaca, NY, 14853

Referee: Dr. S. Ichikawa, Faculty of Science, Department of Regulation Blology, Laboratory of Genetics, Saitama University, Urawa 338, Japan.

* Corresponding author: Geraldo Stachetti Rodrigues, Phone: 55-19-8675633; Fax: 55-19-8675225.

\begin{abstract}
ABSSTRACT: Since the early studies on the genetic effects of chemical and physical agents, species and clones of Tradescantia have been used as experimental subjects, by virtue of a series of favorable genetic characteristics. Bearing just six pairs $(2 n=12)$ of large, easily observable chromosomes, cells from almost every part of the plant, from the root tips to the developing pollen tube, yield excellent material for cytogenetic studies.

As a consequence of the intensive use of Tradescantia in genetic studies, a series of genetic characleristics have been found that offer opportunities for the detection of agents affecting the stability of the genome. At least five such characteristics have been selected as endpoints for the establishment of assays to evaluate mutagenesis. Three of these, root-tip mitosis, pollen-tube, and microspore mitosis are essentially chromosome aberration assays, wherein one observes and evaluales lle visible damage in the chromosomes. A fourth, the stamen-hair mutation assay (Trad-SHM), is a point mutation mitotic assay based on the expression of a recessive gene for flower color in helerozygous plants. The fifth assay is a cytogenetic test based on the formation of micronuclei (Trad-MCN) that result from chromosome breakage in the meiotic pollen mother cells.

This article examines the characteristics and fundamentals of the Trad-MCN and the Trad-SHM assays and reviews the results obtained to date with these systems in the assessment of environmental mutagenesis.
\end{abstract}

KEY WORDS: Tradescantia, environmental mutagenesis, stamen hair mutation, micronuclei, bioindicator, genotoxicity.

\section{TRAD-MCN: FUNDAMENTALS AND DEVELOPMENT OF THE SYSTEM}

Studies of the Tradescantia genome began with the pioneering work of Sax and Edmonds (1933) on the development of the male gametophyte of Tradescantia reflexa Raf. Important observations were made in a sludy of the effects of X-rays on microspores of this species (Sax, 1938). First, it was noticed that meiotic chromosomes were more susceptible to breakage than milotic chromo- 
somes; more importantly, dividing chromosomes were at least ten times more susceptible as resting ones. Second, breaks were not randomly distributed along the chromosomes. Loci positioned closer o the centromeres were more likely to suffer the splitting effects of radiation. These observations led to the conclusion that coiling of the chromosomes after replication, with the consequent mechanical strain involved, would strongly influence susceptibility to mutational events. These inferences were later confirmed in a study of the effects of ${ }^{(6)} \mathrm{Co}$-gamma radiation on $T$. paludosa And. and Woods (Sparrow and Singleton, 1953). The concepts of temporality and sensitivity are important for the selection of bioindicators of mutagenicity, for synchrony in cell development, and timely recovery periods are two decisive factors in the performance of bioassays (Ma, 1979b).

The greater susceptibility of meiotic when compared with mitotic chromosomes was confirmed in a study of the influence of lack of oxygen on meiosis of $T$. paludosa (Steinitz, 1944). This research represented the first attempt to use micronuclei of the pollen mother cells as a direct indication of chromosome fragmentation. A spontaneous level of $0.87 \%$ cells with micronucleus was defined for 7 . paludosa, a rate that rose to $8.0 \%$ for cells under anacrobic conditions at the early stages of prophase. The results corroborated the earlier findings of Sax (1938), indicating that prophase, especially pachytene and diplotene, was the most susceptible stage of meiosis.

The pace of the meiotic stages was characterized further in a study of the differentiation of excised anthers of $T$. paludosa (Taylor, 1950). Approximately 24 h elapsed for the development of the meiotic nucleus from pachytene to early tetrad. This result proved valuable for the definition of the appropriate recovery period required between exposure of the prophase nucleus in the developing inflorescence of Tradescantia and fixation of the material for telrad analysis.
The growing interest during the 19.50s in the radiomimetic (principally genotoxici capabilities of chemical substances suggested the utilization of Tradescantia as a bioindicator. A pollen tube mitosis assay was first used in a comparative study of simple chemical agents in T. paludosa (Smith and Lofty, 1954). Ethylene oxide, a known effective mutagen, ketene (a compound giving conflicting results), and methyl chloride (an alkylating agent of low potency) were compared for inducing chromatid breaks and chromosome erosions and contractions. The pollen tube assay proved effective in detecting genotoxicity, as the results revealed that the more active compounds, ethylene oxide and ketene, caused more extensive and numerous chromosome aberrations of all types. Possibly due to its postulated faster penetration into the cells, methylchloride was effective in causing chromosome breaks. The propitious selection of chemicals in this early research proved instrumental in demonstrating the sensitivity of Tradescantia and showing its capacity for precisely differentiating nearly comparable effects. A series of studies employing this pollen tube chromatid abcrration assay (Ma, 1967; Ma, 1982) was later carried out regarding the effects of the atmospheric pollutant $\mathrm{SO}_{2}$ (Ma, 1982; Ma el al., 1973; Ma and Khan, 1976), ultraviolet lighi (Ma el al., 1971), X-rays (Ma and Wollf, 196.5), and hydroxylurea (Khan and Ma, 1974). A procedure involving the evaluation of sister chromatid exchanges (SCE) in the root lips of Tradescantia for the evaluation of mutagenic agents was also described (Peng and Ma, 1990).

In a series of papers concerning the role of selected nutrients on meiosis, the production of micronuclei in the microspores of T. paludosa was cited as indicative of chromosome breakage (Steffensen, 1953; Steffensen, 1954; Steffensen, 1955). When studying the effects of magnesium ( $\mathrm{Mg}$ ) deficiency on meiosis, the author noted the greater sensitivity of the microspores when compared with 
rool tips, supporting previous evidence of greater susceptibility of meiotic than mitotic cells. Micronuclei were more numerous in the microspores of plants deficient in $\mathrm{Mg}$, calcium (Ca), and sulfur (S). It was pointed out that the first two nutrients were responsible for bonding with macromolecules in the nucleus, contributing to the stability of proteins and DNA. This was demonstrated further by increased susceptibility to X-rays of plants grown on Ca-deficient media because of the relationship of $\mathrm{Ca}$ with sulthydryl groups in nuclear division, parlicularly in spindle formation. A spontaneous micronuclei frequency of $0.84 \%$ was recorded and increased to $3.89 \%$ in plants grown under suboptimal Ca supply (Stelfensen, 1955). This corroborated earlier observations on micronuclei production in $T$. paludosa (Steinitz, 1944).

More than 30 years after Steinitz's observation of micronuclei for the detection of chromosome damage in meiosis, Ma and coworkers (1978) at Brookhaven National Laboratory devised the Micronucleus-in-Tetrad Assay for Environmental Mutagenesis (later referred to as the Trad-MCN assay) (Knasmuller and Ma, 1992; Lower et al., 1984; Ma, 1981b; Ma, 198 lc; Underbrink et al., 1984). Employing the hybrid clone 443() (T. hirsutiflora Bush $\times$ T. subacalis.s Bush) they compared the production of micronuclei in the pollen mother cells with the mutation for pink cells in the stamen hairs of Tradescantia exposed to the known mutagen 1,2dibromoethane (DBE).

By that time, the stamen hair mutation assay (Trad-SHM) (Underbrink et al., 1973b) had been applied extensively and was a wellrecognized test for radiobiological and chemical mutagenesis. The micronucleus assay, however, exhibited an efficiency approximately 36 times as great. This extraordinary sensitivity was credited to the much smaller specificity of the damage needed to produce a micronucleus when compared with a pink mutation. Indeed, it could be assumed that numerous sites in any of the 12 chromosomes of Tradescantia were subjected to damages that could result in a chromosome breakage, hence, in micronuclei. By contrast, only one locus in one chromosome could bear the mutation for pink pigmentation in the cells of the stamen hair (Ma et al., 1978). It must be pointed out that micronuclei frequency in the Trad-MCN assay is greater at the earlier stage of the pollen letrad, and one may assume that some micronuclei are incorporated into nuclei as the pollen matures. This suggests that some micronuclei may result from lagging chromosomes or laggings of unpaired chromosomes, because it is known that associations of homologous chromosomes in meiosis are not always complete, especially in clone 4430.

The great sensitivity and simplicity of the Trad-MCN assay was demonstrated further in experiments in which X-rays at a low dose were compared with two well-known chemical mutagens, ethyl methanesulfonate (EMS) and sodium azide $\left(\mathrm{NaN}_{3}\right)$ in both liquid and gaseous forms (Ma, 1979a). A low dose of $\mathrm{X}$-rays induced high frequencies of micronuclei, that is, $23 \mathrm{MCN} / 100$ tetrads at a 20 -rad X-ray exposure level when compared with $1.8 \mathrm{MCN} / 100$ cells of human lymphocytes at 50-rad of X-rays (Countryman and Headdle, 1976) or $2.5 \mathrm{MCN} / 100$ cells of mouse erythroblasts of bone-marrow culture at 35-rad of X-rays (Jenssen and Ramel, 1976). Although there were $0.2 \%$ pink mutations per rad in the Trad-SHM assay, there were $1.6 \% \mathrm{MCN}$ per rad for the Trad-MCN assay. The dose-response relationship of the Trad-MCN assay to $\mathrm{X}$-rays gave a correlation coefficient of 0.99 . The results obtained for the chemical agents verified these findings, both in relation to sensitivity and the dose-response relationships (Ma, 1979a).

One additional advantage of the TradMCN assay was the short-term exposure needed for completion of a test - only $6 \mathrm{~h}$, followed by a $24-\mathrm{h}$ recovery period to allow the cells treated at prophase to reach the 
scroble tetrad stage. This meintic timetable was tested in a study of the stage of sensitivity using X-ray exposure of $T$. paludosa (Ma et al., 1980). Groups of plant cuttings received a single 35-rad X-ray exposure, after which inflorescences were removed and fixed at 3-h intervals for $48 \mathrm{~h}$. A peak of sensitivity occurred after $24 \mathrm{~h}$ postirradiation, which agrees with the observations of Taylor (1950). A second peak appeared at about $39 \mathrm{~h}$ postirradiation, suggesting that the earlier prophase I and/or premeiotic stages are also very sensitive.

The utilization of the Trad-MCN assay for in situ monitoring of environmental clastogens was proposed after studies involving promutagens (benzo- $\alpha$-pyrene) and polluted sites (Ma, 1979b; Ma, 1981a). No external enzymatic activation was needed, because the enzymatic apparatus was fully functional in the exposed plant cuttings.

A series of limitations of the Trad-MCN assay has been presented. The test obviously provided a relative index of genetic damage. Translocations, inversions, and other types of chromosome and chromatid rearrangements and exchanges would not be revealed as micronuclei. No carcinogenicity information could be easily extrapolated from the frequencies of micronuclei, and the metabolic pathways of mutagenic and promutagenic agents may be quite different in Tradescantia and other subjects (especially mammalian species). Also, the high sensitivity of the system results in day-to-day variation in spontaneous micronuclei frequencies, requiring careful control of experimental conditions and simultaneous control samples (Ma, 1981a).

One additional disadvantage of the TradMCN test was the labor-intensive and timeconsuming procedure for micronucleus scoring in the tetrads (Ma, 1990b). In order to overcome this limitation and to facilitate and standardize the scoring process, a micronucleus image analysis system was devised (Ma et al., 1992d; Xu et al., 1989). The computerized system scoring speed was 3.5 times

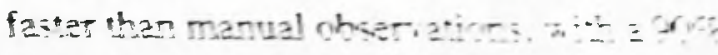
congruity in the frequencies scored.

A relatively recent overview of the in situ monitoring of environmental clastogens (Ma, 1990b) revealed that through 1990 about 300 tests had been conducted with the Trad$\mathrm{MCN}$ assay in a variety of categories. Around $50 \%$ of these tests exhibited genotoxicity. In the following sections, the results obtained to date with the Trad-MCN assay in the evaluation of environmental genotoxicity are reviewed and discussed.

\section{ASSESSMENT OF ENVIRONMENTAL MUTAGENESIS}

\section{A. Air Pollution}

T. paludosa was exposed at several polluted sites in Illinois and to gaseous agents commonly found in polluted atmospheres in a combination of in situ and in vivo laboratory tests (Ma et al.. 1982a: Ma and Harris. 1985; Ma et al., 1989). In situ assays carried out in public parking garages revealed a correlation between the rate of micronuclei production and the volume of traffic, with a positive dose-response (time of exposure, from 2 to $6 \mathrm{~h})$ relationship $(\alpha=0.01)$. A series of in situ exposures of $T$. paludosa and of clone 4430 to industrial sites, farms, and laboratory atmospheres resulted in positive results $(\alpha=0.01)$ in most categories. Atmospheres of an office, a livestock farm, and a residential area gave negative results. A high frequency of micronuclei occurred at a site where gaseous pollutants from an agricultural chemical production plant were prevalent (Ma et al., 1982a).

Tradescantia plants were fumigated with the atmospheric pollutants $\mathrm{NO}_{2}, \mathrm{SO}_{2}$, and $\mathrm{O}_{3}$, as well as gaseous hydrazoic acid $\left(\mathrm{HN}_{3}\right)$ and EMS (Ma et al., 1982a). With the exception of $\mathrm{O}_{3}$, all agents proved clastogenic to Tradescantia. Both $\mathrm{NO}_{2}$ and $\mathrm{SO}_{2}$ required long exposure times (24 and 22 hours, 
respectively), while gaseous $\mathrm{HN}_{3}$ and EMS gave positive results after 6 - $\mathrm{h}$ exposures. In a recent experiment, $\mathrm{O}_{3}$ was shown to be clastogenic in the Trad-MCN assay in concentrations as low as $100 \mathrm{ppb}$ (Rodrigues et al., 1996).

As a consequence of its versatility, Tradescantia was proposed as a monitor of indoor pollution. Several studies have assessed the proficiency of the Trad-MCN assay for the low level of contaminants customarily present in home environments. Among the positive responses found are several common commercial air fresheners, tobacco smoke, $p$-dichlorobenzene (moth balls) and other insecticides listed for residential use, and diesel exhaust gases (Harris and $\mathrm{Ma}$, 1983; Ma el al., 1982b; Ma and Harris, 1987a; Ma and Harris, 1987b; Ma et al., 1983b).

A somewhat unusual group of atmospheric pollutaints evaluated in situ for mutagenicity with the Trad-MCN assay were the chemical smokes employed by the U.S. Army. These tests also involved other assays, including chromosome breakage and sister chromatid exchange in a native rodent (Schaeffer et al., 1987). The smokes were generated from fogoil, tank diesel, and hexachloroethane. All of them induced a higher rate of genotoxic events for at least one dose when compared with the controls in the Trad-MCN assay $(\alpha=0.1)$. The production of chromosome breakage in rodents was depressed. There was a higher degree of variability (expressed as larger standard deviations from the mean micronuclei production) for all in situ treatments relative to controls (Schaeffer et al., 1987). Even though this statistical effect was discussed merely as obscuring the dose-dependence of the results, it might be indicative of a characteristic of the Tradescantia system. The smaller buds of a young inflorescence are hidden beneath larger buds and bracts, which may result in their being protected from unrestricted exposure, especially in atmospheric exposures, an effect anticipated by Ma, (1979b).
In an in situ study with Tradescantia clone 4430 in Mexico (Ruiz et al., 1992), the micronuclei frequency peaks for one heavily industrialized, one residential, and one mixed occupation area were evaluated. Plants exposed to the industrial site always showed higher levels of micronuclei than the controls $(\alpha=0.01)$ throughout the year, whereas the residential area samples tended to be higher than the controls only in specific months.

The Trad-MCN assay gave positive results in assessing the mutagenic risks posed by gaseous emissions from a municipal waste incinerator (Ma et al., 1993b; Ma et al., 1996; Ma et al., 1992b) and from a landfill vent pipe (Ma, 1994b; Ma et al., 1993a; Ma et al., 1996).

From the studies referred to earlier, it may be concluded that the Trad-MCN is well suited for assessing atmospheric contamination, whether from heavily polluted industrial or urban areas or under diurnal indoor environmental conditions. Weather conditions such as variations in wind speed and direction normally led to high levels of statistical variability in the data.

A summary of the results obtained with Tradescantia in assessments of atmospheric pollution and gaseous agents is presented in Table 1 .

\section{B. Water Pollution}

Nearly all studies for evaluating the presence of mutagenic agents in natural waters must incorporate a step to concentrate possible active agents to be evaluated by bioassay or chemical analysis. This happens because of the intrinsic low mutagenicity of the putative agents most frequently present in natural waters, because of the very low concentrations at which they are found, or both.

The necessity for sample concentration was clearly illustrated in an evaluation of the probability of detecting a mutagen in natural 
TABLE 1

Summary of Environmental Genotoxicity Results Using Chromosome Breakage in Tradescantia, with Special Reference to the Trad-MCN Assay of Polluted Atmospheres and Atmospheric Pollutants

\begin{tabular}{|c|c|c|c|c|c|c|}
\hline \multirow[b]{2}{*}{ Agent } & \multicolumn{3}{|c|}{ Dose range } & \multicolumn{2}{|c|}{ Result } & \multirow[b]{2}{*}{ Ref. } \\
\hline & $\begin{array}{l}\text { Exposure } \\
\text { time-max }\end{array}$ & Concentration & $+1-$ & $\begin{array}{l}\text { Statistical } \\
\text { significance }\end{array}$ & Remarks & \\
\hline \multicolumn{7}{|c|}{ In situ Monitoring } \\
\hline \multirow[t]{16}{*}{ Air pollution } & $4-6 h$ & & - & $p<0.01$ & $\begin{array}{l}\text { Parking garage } \\
\text { Chicago, IL }\end{array}$ & $\begin{array}{c}\text { Ma et al., } \\
\text { 1982a }\end{array}$ \\
\hline & $1-4.5 \mathrm{~h}$ & & - & $p<0.01$ & $\begin{array}{l}\text { Clear wind from lake } \\
\text { Parking garage, } \\
\text { Decatur, IL }\end{array}$ & \\
\hline & $2-6 \mathrm{~h}$ & & + & $p<0.01$ & $\begin{array}{l}\text { Parking garage, } \\
\text { Peoria, IL }\end{array}$ & \\
\hline & $2-4 h$ & & - & $p<0.01$ & Truck and bus stop & \\
\hline & $2-3 h$ & & - & $p<0.01$ & Truck and bus stop & \\
\hline & $2.5-5 h$ & & + & $p<0.01$ & Truck and bus stop & \\
\hline & 3 months & & + & $p<0.01$ & $\begin{array}{l}\text { Iridustrial site, } \\
\text { Granite City, IL }\end{array}$ & \\
\hline & $3.5 \mathrm{~h}$ & & + & $p<0.01$ & $\begin{array}{l}\text { Industrial site, } \\
\text { Granite City, IL }\end{array}$ & \\
\hline & $4.5 \mathrm{~h}$ & & - & $p<0.01$ & $\begin{array}{l}\text { Residential area, } \\
\text { China }\end{array}$ & \\
\hline & $4-6 h$ & & + & $p<0.01$ & $\begin{array}{l}\text { Agrochemical indus- } \\
\text { try site, China }\end{array}$ & \\
\hline & $5 \mathrm{~h}$ & & - & $p<0.01$ & Bus station, China & \\
\hline & $6 \mathrm{~h}$ & & + & $p<0.01$ & Bus station, China & \\
\hline & $6 \mathrm{~h}$ & & + & $p<0.01$ & $\begin{array}{l}\text { Rubber company, } \\
\text { China }\end{array}$ & \\
\hline & $4 \mathrm{~h}$ & & - & $p<0.01$ & $\begin{array}{l}\text { Office environment, } \\
\text { China }\end{array}$ & \\
\hline & $3-6 h$ & & + & $p<0.01$ & $\begin{array}{l}\text { P-dichlorobenzene } \\
\text { treated herbarium, } \\
\text { China }\end{array}$ & \\
\hline & $6 \mathrm{~h}$ & & - & $p<0.01$ & $\begin{array}{l}\text { Livestock farm, } \\
\text { swine house } \\
\text { exhaust }\end{array}$ & \\
\hline \multirow[t]{2}{*}{$\begin{array}{l}\text { Diesel exhaust } \\
\text { fumes }\end{array}$} & $23-70 \mathrm{~min}$ & $0.3-4.2 \mathrm{ppm}$ & - & $p<0.01$ & $\begin{array}{l}\text { Concentration mea- } \\
\text { sured as hydro- } \\
\text { carbons; exhaust } \\
\text { generated by run- } \\
\text { ning engine }\end{array}$ & \\
\hline & $23-70 \mathrm{~min}$ & $6-13$ ppm & + & $p<0.01$ & $\begin{array}{l}\text { Concentration mea- } \\
\text { sured as hydro- } \\
\text { carbons; exhaust } \\
\text { generated by run- } \\
\text { ning engine }\end{array}$ & \\
\hline \multicolumn{7}{|c|}{ Gases in chambers } \\
\hline $\mathrm{NO}_{2}$ & $6-24 \mathrm{~h}$ & $5.0 \mathrm{ppm}$ & + & $p<0.01$ & $\begin{array}{c}\text { Positive for longer } \\
\text { exposure only }\end{array}$ & \\
\hline $\mathrm{SO}_{2}$ & $6-22 h$ & 1.0 ppm & + & $p<0.01$ & $\begin{array}{l}\text { Positive for longer } \\
\text { exposure only }\end{array}$ & \\
\hline $\mathrm{O}_{3}$ & $5.5 \mathrm{~h}$ & $5.0 \mathrm{ppm}$ & - & $p<0.01$ & $\begin{array}{l}\text { Longer exposure not } \\
\text { attempted }\end{array}$ & \\
\hline
\end{tabular}


TABLE 1 (continued)

Summary of Environmental Genotoxicity Results Using Chromosome Breakage in Tradescantia, with Special Reference to the Trad-MCN Assay of Polluted Atmospheres and Atmospheric Pollutants

\begin{tabular}{|c|c|c|c|c|c|c|}
\hline \multirow[b]{2}{*}{ Agent } & \multicolumn{3}{|c|}{ Dose range } & \multicolumn{2}{|c|}{ Result } & \multirow[b]{2}{*}{ Ref. } \\
\hline & $\begin{array}{l}\text { Exposure } \\
\text { time-max }\end{array}$ & Concentration & $+1-$ & $\begin{array}{l}\text { Statistical } \\
\text { significance }\end{array}$ & Remarks & \\
\hline $\mathrm{O}_{3}$ & $6 \mathrm{~h}$ & $100 \mathrm{ppb}$ & + & $p<0.01$ & & $\begin{array}{c}\text { Rodrigues } \\
\text { et al., } \\
1996\end{array}$ \\
\hline $\mathrm{HN}_{3}$ & $6 \mathrm{~h}$ & 136-272 ppm & + & $p<0.01$ & $\begin{array}{l}\text { Single application of } \\
\text { gas, without } \\
\text { replenishment }\end{array}$ & $\begin{array}{c}\text { Ma et al. } \\
1982 a\end{array}$ \\
\hline EMS & $6 n$ & 1000 ppm & + & $p<0.01$ & Same as above & \\
\hline $\begin{array}{l}\text { Benzo- } \alpha- \\
\text { pyrene }\end{array}$ & $6 \mathrm{~h}$ & $0.05-0.10 \mathrm{mM}$ & + & $p<0.01$ & & Ma, 1981a \\
\hline $\begin{array}{l}\text { 1,2-dibromo } \\
\text { ethane }\end{array}$ & $6 \mathrm{~h}$ & 5-80 ppm & + & & $\begin{array}{l}\text { Dose response } \\
\text { correl. coefficient } \\
=0.99\end{array}$ & $\begin{array}{c}\text { Ma et al., } \\
1978\end{array}$ \\
\hline $\begin{array}{l}\text { Industrial } \\
\text { district }\end{array}$ & $6-12 \mathrm{~h}$ & & + & $p<0.01$ & $\begin{array}{l}\text { Seasonal variability, } \\
\text { Mexico }\end{array}$ & $\begin{array}{l}\text { Ruiz et at., } \\
1992\end{array}$ \\
\hline $\begin{array}{l}\text { Residential } \\
\text { district }\end{array}$ & $6-12 \mathrm{~h}$ & & + & $p<0.01$ & $\begin{array}{l}\text { Seasonal variability, } \\
\text { Mexico }\end{array}$ & \\
\hline Mixed district & $6-12 \mathrm{~h}$ & & + & $p<0.01$ & $\begin{array}{l}\text { Seasonal variability, } \\
\text { Mexico }\end{array}$ & \\
\hline \multicolumn{7}{|l|}{ Chemical smokes } \\
\hline Fogoil & $30 \mathrm{~min}$ & $\begin{array}{l}15-100 \mathrm{~m} \text { from } \\
\text { smoke source }\end{array}$ & + & $\rho<0.01$ & $\begin{array}{l}\text { Gas concentrations } \\
\text { reported in relative } \\
\text { terms; all distanc- } \\
\text { es produced posi- } \\
\text { tive results }\end{array}$ & $\begin{array}{c}\text { Schaeffer } \\
\text { et al., } \\
1987\end{array}$ \\
\hline Tank diesel & $30 \mathrm{~min}$ & $15-100 \mathrm{~m}$ & + & $p<0.01$ & Same as above & \\
\hline Hexachloro & $30 \mathrm{~min}$ & $15-100 \mathrm{~m}$ & + & $p<0.01$ & Same as above & \\
\hline $\begin{array}{l}\text { Landfill } \\
\text { gaseous } \\
\text { emissions }\end{array}$ & $4-6 h$ & & + & & $\begin{array}{l}\text { Positive responses } \\
\text { in } 5 \text { of } 13 \text { monitor- } \\
\text { ing trips; gases } \\
\text { burned at emission } \\
\text { source }\end{array}$ & $\begin{array}{l}\text { Ma et al., } \\
\text { 1993a; } \\
\text { Ma et al., } \\
1996\end{array}$ \\
\hline $\begin{array}{l}\text { Municipal } \\
\text { incinerator }\end{array}$ & $4-6 h$ & $\begin{array}{l}50-500 \mathrm{~m} \text { from } \\
\text { source }\end{array}$ & + & & $\begin{array}{l}\text { Positive results ob- } \\
\text { tained with stag- } \\
\text { nant atmosphere }\end{array}$ & $\begin{array}{l}\text { Ma et al., } \\
\text { 1993b; } \\
\text { Ma et al., } \\
1996\end{array}$ \\
\hline Dry cleaning & $15 \mathrm{~h}$ & & - & $p<0.05$ & Night hours & $\begin{array}{l}\text { Ma and } \\
\text { Harris, } \\
1987 a ; \\
\text { Ma and } \\
\text { Harris, } \\
1987 b\end{array}$ \\
\hline House & $16 \mathrm{~h}$ & & + & $p<0.05$ & $\begin{array}{l}\text { After carpet } \\
\text { shampooing }\end{array}$ & \\
\hline House & $17 \mathrm{~h}$ & & - & $p<0.05$ & Clean air & \\
\hline Pipe smoke & $24 \mathrm{~h}$ & & + & $p<0.05$ & Within office room & \\
\hline $\begin{array}{l}\text { Tobacco smok- } \\
\text { ing room }\end{array}$ & $10 \mathrm{~h}$ & & + & $p<0.05$ & In a public school & \\
\hline Air fresheners & $1-6 h$ & & + & & Several brands & \\
\hline $\begin{array}{l}\text { Formaldehyde } \\
\text { fumes }\end{array}$ & $1-6 h$ & & + & & $\begin{array}{l}\text { Positive dose- } \\
\text { response relationship }\end{array}$ & \\
\hline
\end{tabular}


waters with the Ames assay (Johnston and Hopke, 1980). The analysis considered a weight-dependent variable, taking into account the mutagenic potency and the average concentration of organic mutagens commonly found in natural waters and the amount of chemical needed to induce a doubling in revertants in the Ames assay. Considering that (1) generally only $1-\mathrm{ml}$ aliquots are assayed in a test plate, (2) organic compounds typically occur in water at $\mu \mathrm{g} / \mathrm{l}$ concentrations, and (3) $95 \%$ of the chemicals tested so far have a doubling dose of at least $1500 \mu \mathrm{g}$, the average environmental sample that would permit the detection of contaminants with $95 \%$ confidence should contain about 15001 . This means that a concentration factor of six orders of magnitude is required to reduce the volume of such a sample for testing. It was concluded that the lifetime exposure of a human to mutagens present in drinking waters could be appreciable despite the failure to detect them in environmental samples (Johnston and Hopke, 1980).

Perhaps the most important feature of the Trad-MCN assay, as well as of certain other plant assays, is its capability to detect low level genotoxicity in either short-term in situ exposures or in vivo tests with unconcentrated water samples (Fang, 1981a; Fang, 1981b). This was demonstrated in a 2-year genotoxicity study of the surface waters of Spring Lake reservoir and of the municipal drinking water obtained from the reservoir in Macomb, IL (Ma et al., 1985). Water samples were drawn from the reservoir biweekly and tested for genotoxicity and for the presence of nutrient elements and metals. The most prominent result of this study was a recurring seasonality in the expression of micronuclei frequency peaks $(\alpha=0.05)$ that occurred following the periods of intense precipitation and runoff from corn and soybean fields upstream from the reservoir. Micronuclei production for the drinking water tended to follow the patterns observed for the reservoir $(\alpha=0.05)$, although the peaks were lower.
In a follow-up investigation, tests were conducted with a chronic mouse-erythrocytemicronucleus test, and additional samples of a shallow- and a medium-depth well located in the same rural area as the reservoir (Ma et al., 1987). A similar pattern of micronucleus frequency $(\alpha=0.01)$ following heavy precipitation or snow thaw were found for the Trad-MCN assay, with delays matching the times supposedly required for the arrival or accumulation of clastogens at the sampling sites. Analyses of water samples for organic compounds from the shallow well exhibited elevated levels of methylene chloride, dichlorobromoethane, trichloroethylene, and tetrachloroethylene. The mouse assays confirmed these results, although 6-month exposures to the mutagenic samples (when compared with 30-h exposures for Tradescantia) were required for a significant $(\alpha=0.03)$ increase in micronuclei frequencies to occur.

The quickness and simplicity of the TradMCN test (Ma, 1994a; Ma and Cabrera, 1986) have prompted its application to the study of a variety of water samples, for example, industrial effluents (Chen et al., 1984; Chen and Xiang, 1983; Ruiz et al., 1987; Zheng, 1985), surface waters and landfill leachates (Ma et al., 1992c), sea water and marine pollution (Chen, 1982; Chen et al., 1983; Chen and Fang, 1981; Chen et al., 1988; Chen et al., 1989; Chen and Zheng, 1982; Chen and Zhou, 1985), groundwater (Helma et al., 1992), and drinking water (Helma et al., 1994a; Lo, 1985).

The experiments described for the detection of genotoxicity in natural waters cannot be qualified as in situ, because in all cases samples were brought to the laboratory and assayed under controlled conditions. Appropriate evaluation of in situ mutagenicity in aquatic environments became possible after the introduction of the "aquatoon", a floating device specifically designed to hold plant material for exposure to water bodies. The aquatoon was employed successfully in an in situ genotoxicity study of the effluents of a pulp and paper mill on the north shore 
of Lake Superior (Grant et al., 1992). The Tradescantia (clone 4430) micronucleus and stamen-hair-mutation assays, and the Vicia faba L. rool tip chromosomal aberration assay were performed in the creek containing the raw effluents and in the bay into which the creek emptied. The Trad-MCN and $V$. faba assays showed positive responses after 24-h exposures at both sites $(\alpha=0.05)$. There was partial agreement between the genotoxic effects and the optical density of the samples. In addition to being more sensitive, the two tests that showed the best results were much better adapted to in situ studies. The material could be fixed immediately after exposure, whereas the stamen hair mutation assay requires a long recovery period under conditions that cannot be atlained in the field or during transportation.

In a study of industrial wastewater in Mexico, a higher level of micronuclei production was found relative to tapwater controls $(\alpha=0.01)$, even after a dilution to $1 / 3$ strength (Ruiz et al., 1992). Seasonal variations observed in the data could not be correlated to any environmental parameter measured. One interesting aspect of these experiments was the lower than normal spontaneous frequency of micronuclei found in Tradescantia (0.8 to $1.5 \mathrm{MCN} / 100$ tetrads). It was postulated that the high elevation and subtropical climate typical of the region could be more favorable to growth of clone 4430 due to its genetic relationship to the alpine species $T$. hirsutiflora.

The leachates of an abandoned 20-yearold landfill were tested for genotoxicity with the Trad-MCN assay (Ma et al., 1993a). The high toxicity of the samples precluded tests with solutions diluted less than tenfold, whereas genotoxicity could still be detected in 20fold dilutions of the leachate samples.

The genotoxicity of contaminated groundwaters treated in a purification plant designed to clean one of the most important aquifers in Austria were assessed in a series of experiments with the Trad-MCN assay (Helma et al., 1992; Helma et al., 1993;
Helma et al., 1994b). The purification methods consisted of activated charcoal filtration and UV irradiation. Samples drawn before any treatment exhibited positive, dose-dependent clastogenic effects $(\alpha=0.05)$ after a 24-h exposure. When treated in the laboratory with increasing amounts of UV light (up to $1500 \mathrm{~J} / \mathrm{m}^{2}$ ), these samples induced micronuclei formation in a dose-dependent fashion relative to UV applied. Results for irradiated clean tapwater were negative. Chemical parameters routinely measured at the purification plant indicated that the activated charcoal-filtered samples were of drinking water quality. In many cases, however, higher micronuclei frequencies were found for these samples before or after UV irradiation. The mechanism responsible for the effects observed was postulated to be activation of water pollutants to genotoxic compounds by UV irradiation. The enhancement of clastogenicity by UV light decreased after storage, with an estimated half-life of approximately $1 \mathrm{~d}$. The authors concluded that similar UV light treatment of waters for drinking could produce hazardous compounds that might pass undetected in the treatment plants.

Studies on water pollution demonstrate the capabilities and advantages of the Trad-MCN assay for the in situ assessment of environmental genotoxicants. The ability to detect biological effects in samples considered clean by most chemical standards and the absence of any requirements for tedious concentration procedures that may result in loss and chemical alteration of the compounds are undoubtedly desirable characteristics of this system.

Table 2 presents a summary of results obtained with Tradescantia in the evaluation of water pollutants.

\section{Soil Contaminants and Soil Amendments}

Several studies have evaluated the mutagenicity of soils in situ, of extracts of soils from contaminated sites (Ho et al., 1983) be- 
TABLE 2

Summary of Environmental Genotoxicity Results Using Chromosome Breakage in Tradescantia, with Special Reference to the Trad-MCN Assay of Water Pollutants

\begin{tabular}{|c|c|c|c|c|c|c|}
\hline \multirow[b]{2}{*}{ Agent } & \multicolumn{3}{|c|}{ Dose range } & \multicolumn{2}{|c|}{ Result } & \multirow[b]{2}{*}{ Ref. } \\
\hline & $\begin{array}{l}\text { Exposure } \\
\text { time-max }\end{array}$ & Concentration & $+1-$ & $\begin{array}{l}\text { Statistical } \\
\text { significance }\end{array}$ & Remarks & \\
\hline \multicolumn{7}{|l|}{ Water pollution } \\
\hline Drinking water & $30 \mathrm{~h}$ & & + & $p<0.05$ & $\begin{array}{l}\text { Both lake and tap- } \\
\text { water produced } \\
\text { peaks in } \mathrm{MCN} \\
\text { frequency follow- } \\
\text { ing rainy season }\end{array}$ & $\begin{array}{l}\text { Ma et al., } \\
1985\end{array}$ \\
\hline Drinking water & $30 \mathrm{~h}$ & & + & & $\begin{array}{l}\text { Lake, shallow- and } \\
\text { medium-depth } \\
\text { well waters } \\
\text { analyzed; MCN } \\
\text { frequency in- } \\
\text { creased following } \\
\text { rainy season }\end{array}$ & $\begin{array}{c}\text { Ma et al. } \\
1987\end{array}$ \\
\hline $\begin{array}{l}\text { In situ expo- } \\
\text { sure to lake } \\
\text { water }\end{array}$ & $24 \mathrm{~h}$ & & + & $p<0.05$ & $\begin{array}{l}\text { Lake Superior and } \\
\text { inlet polluted by } \\
\text { pulp and paper } \\
\text { mill effluent }\end{array}$ & $\begin{array}{c}\text { Grant et al., } \\
1992\end{array}$ \\
\hline Wastewater & $30 \mathrm{~h}$ & $\begin{array}{c}\text { Threefold } \\
\text { dilution }\end{array}$ & + & $p<0.01$ & $\begin{array}{l}\text { Industrial effluents } \\
\text { presents; positive } \\
\text { responses over } \\
\text { entire year }\end{array}$ & $\begin{array}{c}\text { Ruiz et al., } \\
1992\end{array}$ \\
\hline $\begin{array}{l}\text { Landfill } \\
\quad \text { leachates }\end{array}$ & & $\begin{array}{l}\text { 20-fold } \\
\text { dilution }\end{array}$ & + & & & $\begin{array}{c}\text { Ma et al., } \\
1993 a\end{array}$ \\
\hline Groundwater & $30 \mathrm{~h}$ & $\begin{array}{l}\text { Threefold } \\
\text { dilution }\end{array}$ & + & $p<0.05$ & $\begin{array}{l}\text { PAH-contaminated } \\
\text { groundwater; } \\
\text { UV treatment } \\
\text { increased } \\
\text { mutagenicity }\end{array}$ & $\begin{array}{l}\text { Helma et } \\
\text { al., 1993; } \\
\text { Helma et } \\
\text { al., 1994b }\end{array}$ \\
\hline
\end{tabular}

fore and after the application of remediation measures, and of soil amendment materials themselves. Perhaps the most voluminous soil amendment used throughout the world is municipal sewage sludge. Generally, the impact of this material on the environment has been judged by its heavy metal contamination (L'Hermite and Dehandtschttler, 1980). However, complex organic compounds are sometimes introduced into the sewage treatment systems. The possible mutagenicity of such sludges from Chicago was evaluated utilizing two higher plant assays (Zea mays L. and Tradescamia) and two strains of Salmonella in the histidine reversion test (Hopke et al., 1982). Laboratory tests with $T$. paludosa, showed that sludge dilutions above $1: 4$ showed increased micronuclei frequency. This result was in agreement with results obtained for other species.

The clastogenicity of several chemicals commonly found in hazardous-waste sites were evaluated in a series of experiments aimed at elucidating the possible synergistic or antagonistic behavior of chemical mixtures in the Trad-MCN assay (Ma, 1989; Ma, 1990a; Sandhu et al., 1989). Initially, seven chemicals selected from the U.S. EPA Superfund Priority 1 chemical list (Waters et al., 1987) were tested to determine their minimum effective doses (MED). Five of seven chemicals tested produced positive results ( $\alpha=0.05$ ), and could be ranked in descending order according to their MED in the 
Trad-MCN as follows: lead tetraacetate in D) MSO (0.4 ppm), heplachlor in DMSO (2.0 ppm), dieldrin in DMSO (3.8 ppm), arsenic trioxide in $\mathrm{NaOH}(4.0 \mathrm{ppm})$, and 1,2benzl $a, h \mid$ anthracene in ethanol ( $12.5 \mathrm{ppm})$. Both tetrachloroethylene (TCE) and aldrin were immiscible with water, precluding adequate exposure in solution. When exposed in the gaseous state at $30 \mathrm{ppm}$ for $2 \mathrm{~h}, \mathrm{TCE}$ gave a positive response $(\alpha=0.05)$, but aldrin did not (Sandhu et al., 1989).

Armed with these data, Ma and co-workers (1992a) assessed the clastogenicity of chemical mixtures. All mixtures of TCE (a nonclastogen) and dieldrin (at a concentration below the MED) gave positive results $(\alpha=0.05)$, suggesting a synergistic relationship. Surprisingly, all mixtures of lead tetraacelate and arsenic trioxide (both potent clastogens) proved negative, suggesting an antagonistic relationship. This effect was believed to result from a neutralization of the acid (from acetate) and the base (from sodium hydroxide) that dissolved arsenic trioxide. The other combinations were generally slightly antagonistic, especially for the combined action of three agents. Some mixtures were toxic, preventing the normal development of tetrads. This complex and frequently unpredictable response induced by chemical mixtures led the authors to conclude that in situ evaluations are warranted when multiple compounds interact, such as normally happens in hazardous-waste sites.

Gill and Sandhu (1992) expanded on these findings by testing the same chemicals after soil incorporation using rooted Tradescantia plants. Most of the results agreed with those previous, but in some instances interactions within soil altered the expression of clastogenicity. For example, arsenic trioxide and lead tetraacetate did not induce increased micronuclei production in solution (as in $\mathrm{Ma}$ el al., 1992a), but did so in soil. In general, rooted plants showed higher micronuclei frequencies for the same chemical mixlures than cultings treated in solution. A possible en- hancement of metabolic activation of such mixtures in the root systems and/or by soil microorganisms was suggested as a likely reason. These results demonstrated once again that predicting the genotoxic effects of chemical mixtures from their components was not feasible and emphasized the imporlance of in situ assessments.

The significance of these conclusions was accentuated by the demonstration that tannic acids may act as synergistic compounds in the induction of clastogenicity in Tradescantia (Knasmuller et al., 1992). Exposure of Tradescantia for $24 \mathrm{~h}$ to increasing amounts of tannic acids caused a dramatic dose-dependent increase in the clastogenic effects of X-rays (35 rad), whereas tannic acids alone showed only moderate genotoxicity. Similar results were obtained with tannic acids in combination with other chemicals. This result may be important because tannic acids are present in many foods and beverages, as well as in natural waters and soils. Therefore, practically all chemicals released into the environment may interact with, and be potentiated by, tannic acids.

The value of the Trad-MCN assay as a tool in environmental assessment was emphasized once again in an evaluation of bioremediation measures at a hazardous waste site (Baud-Grasset et al., 1993a; Baud-Grasset et al., 1993b). Heavily creosote-contaminated soils (more than $5000 \mathrm{ppm}$ polyaromatic hydrocarbons) were incubated with the lignin-degrading fungus Phanerochaete chysosporium Burdsall for 8 weeks. Aqueous extracts of soils before and after incubation were evaluated for clastogenicity with the Trad-MCN. Extracts of the original soils were highly clastogenic, with the lowest effective concentration being $0.25 \%$ for a $3($ )-h exposure. Phanerochaete caused a decrease in soil contamination, doubling the concentration of extract needed to induce a micronuclei frequency similar to that before incubation (from 1 to $2 \%$ ). The Trad-MCN assay again proved to be extraordinarily sensitive, 
permitting the detection of differences between closely comparable samples.

The results obtained with Tradescantia in the assessment of soil contaminants are summarized in Table 3.

\section{Pesticides and Health-Related Agents}

Plants are the main biologic receptors of pesticides applied in the field. Thus, it is not surprising that a great deal of attention has been directed to the genotoxicity of pesticides in plants (Mohammad and Ma, 1983). An extensive review of the genetic toxicology of pesticides in higher plant systems (Sharma and Panneerselvan, 1990) listed a total of 178 active ingredients that have been tested in at least one of 31 different plant species, utilizing a variety of organs and genetic endpoints. Approximately $30 \%$ of these compounds were found to be genotoxic, whereas only $6 \%$ could be unequivocally considered to be free of such genetic hazards.

Tradescantia appeared only once in that review, indicating that this assay has not been among the preferred systems for pesticide evaluation of genotoxicity despite its sensitivity and amenability for field testing. The earliest references in which Tradescantia was employed to test pesticide genotoxicity involved the cytological effects of the insecticide mevinphos and the herbicide cyanazine (Ahmed and Grant, 1972b), and the mercurycontaining seed treatment fungicide Panogen $15^{\circledR}$ (methylmercury dicyandiamide) (Ahmed and Grant, 1972a). In these cases, chromo-

TABLE 3

Summary of Environmental Genotoxicity Results Using Chromosome Breakage in Tradescantia, with Special Reference to the Trad-MCN Assay of Soil Amendments and Contaminants

\begin{tabular}{|c|c|c|c|c|c|c|}
\hline \multirow[b]{2}{*}{ Agent } & \multicolumn{3}{|c|}{ Dose range } & \multicolumn{2}{|c|}{ Result } & \multirow[b]{2}{*}{ Ref. } \\
\hline & $\begin{array}{l}\text { Exposure } \\
\text { time-max }\end{array}$ & Concentration & $+1-$ & $\begin{array}{l}\text { Statistical } \\
\text { significance }\end{array}$ & Remarks & \\
\hline \multicolumn{7}{|c|}{ Soil contaminants } \\
\hline Sewage sludge & $24 \mathrm{~h}$ & 4-fold dilution & + & & & $\begin{array}{l}\text { Hopke et } \\
\quad \text { al., } 1982\end{array}$ \\
\hline Aldrin & $30 \mathrm{~h}$ & 2.0-36 ppm & - & $p<0.05$ & & $\begin{array}{r}\text { Sandhu et } \\
\text { al., } 1989\end{array}$ \\
\hline $\begin{array}{l}\text { Tetrachloro } \\
\text { ethylene }\end{array}$ & $2 \mathrm{~h}$ & $30 \mathrm{ppm}$ & + & $p<0.05$ & $\begin{array}{l}\text { Positive only when } \\
\text { exposed in gas- } \\
\text { tous form }\end{array}$ & \\
\hline $\begin{array}{l}\text { Arseninc } \\
\text { trioxide }\end{array}$ & $30 \mathrm{~h}$ & $3.96 \mathrm{ppm}$ & + & $p<0.05$ & Diluted in $\mathrm{NaOH}$ & \\
\hline $\begin{array}{c}\text { 1,2-benz }[a, h] \\
\text { anthrnent }\end{array}$ & $30 \mathrm{~h}$ & $12.5 \mathrm{ppm}$ & + & $p<0.05$ & Diluted in ethanol & \\
\hline Dieldrin & $30 \mathrm{~h}$ & $3.81 \mathrm{ppm}$ & + & $p<0.05$ & Diluted in DMSO & \\
\hline Heptachlor & $30 \mathrm{~h}$ & $1.88 \mathrm{ppm}$ & + & $p<0.05$ & Diluted in DMSO & \\
\hline $\begin{array}{l}\text { Lead tetra- } \\
\text { acetate }\end{array}$ & $30 \mathrm{~h}$ & $0.44 \mathrm{ppm}$ & + & $p<0.05$ & Diluted in DMSO & \\
\hline $\begin{array}{l}\text { Hazardous- } \\
\text { waste site } \\
\text { soil }\end{array}$ & $30 \mathrm{~h}$ & $\begin{array}{l}0.5 \% \text { aqueous } \\
\text { extract }\end{array}$ & $\begin{array}{l}+ \\
+\end{array}$ & $\begin{array}{l}p<0.05 \\
p<0.05\end{array}$ & $\begin{array}{l}\text { Over } 5000 \mathrm{ppm} \\
\text { mixed PAHs }\end{array}$ & $\begin{array}{l}\text { Baud- } \\
\text { Grasset } \\
\text { et al., } \\
\text { 1993a; } \\
\text { Baud- } \\
\text { Grasset } \\
\text { et al., } \\
\text { 1993b }\end{array}$ \\
\hline
\end{tabular}


somal aberration in root tip mitosis was rested. Ahmed and Grant (1972b) reported that mevinphos and cyanazine induced augmented aberration frequencies, but exposures were very high $(200$ to $600 \mathrm{ppm})$, considered to be too extreme in terms of environmental contamination. They found that concentrations of Panogen $15^{*}$ as low as 10 ppm caused cylotoxicily, whereas clear genotoxicity was noticed with just 1 ppm (Ahmed and Grant, 1972a). These results might have been significant for human exposure in mixing and spraying operations.

Acknowledging the special merit of in situ studies of agricultural chemicals, Grant, (1982) opined that no organisms were as useful as Tradescantia or was any test as adequate as the Trad-MCN for the evaluation of the genetic hazards in situ. These assertions were soon tested in a study of the genotoxicity of the insecticide malathion used for pest control in a greenhouse (Ma et al., 1983a). In one treatment, intact potted plants were sprayed with malathion in the greenhouse, simulating conventional pest control treatment. Additional treatments involved absorption of malathion solutions through stems (will and without prior DMSO dissolution or treatment with $\mathrm{S}-9$ microsome fraclion of Arochlor ${ }^{\text {TM}}$-induced mouse liver macerate) and exposure of intact plants to heat-generated malathion fumes in air-tight chambers. All exposures to malathion solutions, whether sprayed or absorbed through the stems, were negative. Exposure of cuttings to fumes of malathion resulted in a striking increase in micronuclei frequencies, suggesting that gaseous forms of some pesticides may be particularly effective in the Trad-MCN assay (Ma et al., 1983a).

The clastogenicity of Benlate ${ }^{\circledR}$ (benomyl) and thiophanate, two fungicide products used in fruit storage, were evaluated with the Trad-MCN assay at concentrations of 0.05 and $0.07 \%$, respectively (Huang and Chen, 1993b; Huang and Chen, 1993c). Both agents induced high levels of micronuclei. Several pesticides were evaluated in a large scale study of the genotoxicity of health related agents (Ma et al., 1984) (see below). Among the positive results were dicamba, dichlorvos fumes, chlorpyrifos, gaseous malathion, $p$ dichlorobenzene, and Tordon ${ }^{\circledR}$ (picloram). Atrazine, 2,4-D, liquid malathion, and simazine were among the negative results. Eleven of the 18 pesticide agents tested in this study gave posilive results. Of eight pesticides tested, both in the Trad-MCN and in the Ames test, only one (simazine) gave different results in the two tests.

Rodrigues (1995) assessed in situ the abatement of pesticide genotoxicity in an integrated pest management program for corn/ soybean. All three pesticides applied cyanazine, metolachlor, and chlorpyrifos showed clastogenic activity both in situ and under laboratory conditions. Extracts of pesticide-sprayed soils were also positive.

Results obtained to date for the clastogenicity of pesticides in Tradescantia are summarized in Table 4.

Ma and co-workers (1984) presented the results of 140 Trad-MCN assays performed with a variety of chemical and physical agents. The agents were classified in nine categories (numbers in brackets indicate number of agents tested in the category): (1) known carcinogens/mutagens [15], (2) common beverages [8], (3) common chemicals [30], (4) common drugs [32], (5) pesticides (discussed above) [18], (6) common household chemicals [16], (7) ionizing radiation and radioisotopes [3], (8) in situ monitoring [13], and (9) complex environmental mixtures [8]. Some positive results within these groupings were (1) benzo- $\alpha$-pyrene $(50 \mathrm{mM})$, EMS (50 $\mathrm{mM})$, and sodium azide $(0.2 \mathrm{mM})$; (2) ethanol (5\%), decaffeinated coffee $(25 \%)$, and cola (50\%); (3) formaldehyde fumes, nitrous oxides, and sulfur dioxide; (4) saccharin, aspirin; (5) some air-fresheners and cosmetics; (6) all ionizing radiation; (7) several polluted sites; and (8) several types of combustion exhausts and unconcentrated 
TABLE 4

Summary of Environmental Genotoxicity Results Using Chromosome Breakage in Tradescantia, with Special Reference to the Trad-MCN Assay of Selected Pesticides

\begin{tabular}{|c|c|c|c|c|c|c|}
\hline \multirow[b]{2}{*}{ Agent } & \multicolumn{3}{|c|}{ Dose range } & \multicolumn{2}{|c|}{ Result } & \multirow[b]{2}{*}{ Ref. } \\
\hline & $\begin{array}{l}\text { Exposure } \\
\text { time-max }\end{array}$ & Concentration & $+1-$ & $\begin{array}{l}\text { Statistical } \\
\text { significance }\end{array}$ & Remarks & \\
\hline \multicolumn{7}{|l|}{ Pesticides } \\
\hline Mevinphos & $3-12 h$ & $200-600$ ppm & + & $p<0.001$ & Root tip mitosis & $\begin{array}{l}\text { Ahmed and } \\
\text { Grant, } \\
\text { 1972a; } \\
\text { Ahmed and } \\
\text { Grant, } \\
\text { 1972b }\end{array}$ \\
\hline Cyanazine & $3-12 h$ & 200-600 ppm & + & $p<0.001$ & Root tip mitosis & \\
\hline $\begin{array}{l}\text { Panogen } 15^{\circledR} \\
\text { (mercurial) }\end{array}$ & $1-3 h$ & $1-5 \mathrm{ppm}$ & + & $p<0.05$ & Root tip mitosis & $\begin{array}{c}\text { Ahmed and } \\
\text { Grant, } \\
\text { 1972a }\end{array}$ \\
\hline Malathion & $6 \mathrm{~h}$ & $5.5-1650 \mathrm{ppm}$ & - & $p<0.05$ & $\begin{array}{l}\text { Stem absorption } \\
\text { and spray } \\
\text { application }\end{array}$ & $\begin{array}{l}\text { Ma et al., } \\
\quad 1983 a\end{array}$ \\
\hline Malathion & $6 \mathrm{~h}$ & $0.25-0.65 \%$ & + & $p<0.05$ & $\begin{array}{l}\text { Heat-generated } \\
\text { fumes }\end{array}$ & \\
\hline Malathion & $6 \mathrm{~h}$ & 4125 ppm & - & $p<0.05$ & $\begin{array}{l}\text { Applied as liquid } \\
\text { Negative in the } \\
\text { Ames test }\end{array}$ & $\begin{array}{l}\text { Ma et al., } \\
1984\end{array}$ \\
\hline $\begin{array}{l}\text { Malathion } \\
\text { acetate }\end{array}$ & $6 \mathrm{~h}$ & $1.27 \%$ & + & $p<0.05$ & Applied as a gas & \\
\hline Atrazine & $6 \mathrm{~h}$ & $200 \mathrm{ppm}$ & - & $p<0.05$ & $\begin{array}{c}\text { Positive in the } \\
\text { Ames test }\end{array}$ & \\
\hline Cyanazine & $6 \mathrm{~h}$ & $400 \mathrm{ppm}$ & + & $p \cong 0.05$ & $\begin{array}{l}\text { Negative in some } \\
\text { trials }\end{array}$ & \\
\hline Simazine & $6 \mathrm{~h}$ & 200 ppm & - & $p<0.05$ & $\begin{array}{l}\text { Negative in the } \\
\text { Ames test }\end{array}$ & \\
\hline Dicamba & $6 \mathrm{~h}$ & 200 ppm & + & $p<0.05$ & $\begin{array}{l}\text { Toxic above } 50 \mathrm{ppm} \\
\text { (MED) }\end{array}$ & \\
\hline Dichlorvos & $6 \mathrm{~h}$ & $0.5 \%$ & + & $p<0.05$ & $\begin{array}{l}\text { Applied as gas; pos- } \\
\text { itive in the Ames } \\
\text { test }\end{array}$ & \\
\hline $2,4-D$ & $6 \mathrm{~h}$ & $200 \mathrm{ppm}$ & - & $p<0.05$ & $\begin{array}{c}\text { Negative in the } \\
\text { Ames test }\end{array}$ & \\
\hline Chlorpyrifos & $6 \mathrm{~h}$ & $400 \mathrm{ppm}$ & + & $p \equiv 0.05$ & $\begin{array}{l}\text { Negative in some } \\
\text { trials }\end{array}$ & \\
\hline Picloram & $6 \mathrm{~h}$ & 200 ppm & + & $p<0.05$ & MED 200 ppm & \\
\hline $\begin{array}{l}\text { Maleic } \\
\text { hydrazide }\end{array}$ & $6 \mathrm{~h}$ & 50 ppm & + & $p<0.05$ & $\begin{array}{c}\text { Positive in the } \\
\text { Ames test }\end{array}$ & \\
\hline Cyanazine & $30 \mathrm{~h}$ & 10 ppm & + & $p<0.05$ & $\begin{array}{l}\text { 50-ppm solutions } \\
\text { were toxic }\end{array}$ & $\begin{array}{c}\text { Rodrigues, } \\
1995\end{array}$ \\
\hline Metolachlor & $30 \mathrm{~h}$ & 50 ppm & + & $p<0.05$ & & \\
\hline Chlorpyrifos & $30 \mathrm{~h}$ & 50 ppm & + & $p<0.05$ & $\begin{array}{l}\text { A combination of } \\
\text { these last three } \\
\text { compounds ap- } \\
\text { plied to soil pro- } \\
\text { duced positive } \\
\text { results in situ }\end{array}$ & \\
\hline
\end{tabular}


TABLE 4 (continued)

Summary of Environmental Genotoxicity Results Using Chromosome Breakage

in Tradescantia, with Special Reference to the Trad-MCN Assay of Selected Pesticides

\begin{tabular}{|c|c|c|c|c|c|c|}
\hline \multirow[b]{2}{*}{ Agent } & \multicolumn{3}{|c|}{ Dose range } & \multicolumn{2}{|c|}{ Result } & \multirow[b]{2}{*}{ Ref. } \\
\hline & $\begin{array}{l}\text { Exposure } \\
\text { time-max }\end{array}$ & Concentration & $+l-$ & $\begin{array}{l}\text { Statistical } \\
\text { significance }\end{array}$ & Remarks & \\
\hline Dichlorvos & $1-6 \mathrm{~h}$ & & + & & Insecticide & $\begin{array}{r}\text { Ma and } \\
\text { Harris } \\
1987 \mathrm{~b}\end{array}$ \\
\hline Benlate $^{(t)}$ & & $0.05 \%$ & + & & & $\begin{array}{l}\text { Huang } \\
\text { and } \\
\text { Chen, } \\
\text { 1993b } \\
\text { Huang } \\
\text { and } \\
\text { Chen, } \\
\text { 1993c }\end{array}$ \\
\hline
\end{tabular}

contaminated waters. Among the negative results were some potent mutagens, for example, (1) 1,2-benzanthacene, methyl methanesulfonate (overdose occurred by exposure to 1 to $50 \mathrm{~m} M$ ), and dinitrotoluene; and (4) mitomycin C (1 to $30 \mathrm{ppm}$ ). Of 39 agents tested with the Trad-MCN assay and for which results of Ames tests were available, 26 gave the same results in both tests, representing a congruity of $67 \%$ (Ma et al., 1984). Tradescantia has been employed also in the evaluation of genotoxicity of medicines (Chen and Guan, 1988; Zhang et al., 1994), and various chemicals of environmental concern (Helma et al., 1995; Ma, 1993).

The results available to date with Tradescantia in the evaluation of the clastogenic properties of selected chemical agents and physiological stresses are presented in Table 5.

\section{E. Radiation, Cosmic Rays, and Radiowaves}

T. palludosa was used to study the potential effects of factors associated with space flight, such as acceleration, vibration, weightlessness, and ionizing radiation (Delone et al., 1986). Inflorescences were fixed chemi- cally at several times from take-off to postlanding, and the mitotic figures of the microspores were analyzed for aberrations. One very special aberration was observed in this material, especially for microspores exposed at early prophase. It consisted of complex nonreciprocal translocations involving spherical fragments. The appearance of such rearrangements was not associated with the duration of flight or with take-off or landing. It was speculated that the causative agent of these aberrations was a heavy bombardment by cosmic radiation (Delone et al., 1986). In another study (Marimuthu et al., 1972), the effects of space flight on the development of the female gametophytes of Tradescantia clone 02 were evaluated. Misorientation of the nuclei suggested that malfunction of the spindles could be associated with exposure to free flight.

The sensitivity of Tradescantia to radiation has been demonstrated for X-rays (Ma et al., 1982c), external and internal radioisotope sources (Anderson and Ma, 1981; Anderson and Ma, 1982; Kirby-Smith and Daniels, 1953), and cosmic rays. Likewise, long-wave radio frequencies and short-wave electromagnetic fields occurring in the vicinity of broadcasting antennae have been shown to be harmful 
TABLE 5

Summary of Environmental Genotoxicity Results Using Chromosome Breakage in Tradescantia, with Special Reference to the Effects of Physiological Stresses and Selected Chemical Agents on the Trad-MCN Assay

\begin{tabular}{|c|c|c|c|c|c|c|}
\hline \multirow[b]{2}{*}{ Agent } & \multicolumn{3}{|c|}{ Dose range } & \multicolumn{2}{|r|}{ Result } & \multirow[b]{2}{*}{ Ref. } \\
\hline & $\begin{array}{l}\text { Exposure } \\
\text { time-max }\end{array}$ & Concentration & $+1-$ & $\begin{array}{l}\text { Statistical } \\
\text { significance }\end{array}$ & Remarks & \\
\hline \multicolumn{7}{|c|}{ Selected chemicals } \\
\hline EMS & $24 h$ & $50-100 \mathrm{mM}$ & + & & $\begin{array}{l}\text { Aqueous solution } \\
\text { absorbed through } \\
\text { the stems }\end{array}$ & Ma, 1979a \\
\hline $\begin{array}{l}9 \text { chemical } \\
\text { categories }\end{array}$ & & & & & $\begin{array}{l}140 \text { chemicals } \\
\text { assayed, } 52 \text { were } \\
\text { positive, } 20 \text { were } \\
\text { borderline, and } 5 \\
\text { were toxic }\end{array}$ & $\begin{array}{c}\text { Ma et al., } \\
1984\end{array}$ \\
\hline \multicolumn{7}{|c|}{ Physiological stresses } \\
\hline Anaerobiosis & $12-48 h$ & Max. $2 \%$ & + & & $\begin{array}{l}\text { Increase chromo- } \\
\text { some breakage, } \\
\text { including micro- } \\
\text { nuclei in micro- } \\
\text { spores }\end{array}$ & $\begin{array}{c}\text { Steinitz, } \\
1944\end{array}$ \\
\hline $\begin{array}{l}\text { Magnesium } \\
\text { deficiency }\end{array}$ & Continuous & $<1 \mathrm{ppm}$ & + & $p<0.001$ & $\begin{array}{l}\text { Abnormal chromo- } \\
\text { some replication } \\
\text { and micronuclei } \\
\text { at meiosis }\end{array}$ & $\begin{array}{c}\text { Steffensen, } \\
1953\end{array}$ \\
\hline $\begin{array}{l}\text { Sulfate } \\
\text { deficiency }\end{array}$ & Continuous & $4.0 \mathrm{ppm}$ & + & $\rho<0.001$ & Same as above & $\begin{array}{c}\text { Steffensen, } \\
1954\end{array}$ \\
\hline $\begin{array}{l}\text { Calcium } \\
\text { deficiency }\end{array}$ & Continuous & $2.5 \mathrm{ppm}$ & + & $p<0.001$ & Same as above & $\begin{array}{l}\text { Steffensen, } \\
1955\end{array}$ \\
\hline
\end{tabular}

to replicating chromosomes. In a series of experiments in situ (Haider et al., 1994), Tradescantia cuttings were exposed at five distances from the antennae, in Faraday (electromagnetic shielding) and plastic (nonshielding) cages distributed around sites that exceeded the International Radiation Protection Association standards for electric field strength. All treatments resulted in high micronuclei frequencies when compared with laboratory controls $(\alpha=0.05)$ and, more importantly, comparison between unshielded and Faraday cageshielded groups showed highly significant differences ( $\alpha=0.004$ ) (Haider et al., 1994). This result is particularly interesting, because both groups were exposed to exactly the same environmental conditions except for the in- fluence of electromagnetic radiation. A doseresponse relationship over distance supports the results that the effects observed were due to the electromagnetic fields.

The clastogenic effects of X-rays and other ionizing radiation on Tradescantia are summarized in Table 6.

\section{TRADESCANTIA STAMEN HAIR ASSAY}

The stamen-hair mutation assay (TradSHM) is a point mutation (mitotic) assay in which expression of the heterozygous dominant blue character of the stamen hair cells is prevented, resulting in the appearance of the 
TABLE 6

Summary of Environmental Genotoxicity Results Using Chromosome Breakage in Tradescantia, with Special Reference to the Trad-MCN Assay of X-rays and Other Radiation

\begin{tabular}{|c|c|c|c|c|c|c|}
\hline \multirow[b]{2}{*}{ Agent } & \multicolumn{3}{|c|}{ Dose range } & \multicolumn{2}{|c|}{ Result } & \multirow[b]{2}{*}{ Ref. } \\
\hline & $\begin{array}{l}\text { Exposure } \\
\text { time--max }\end{array}$ & Concentration & $+1-$ & $\begin{array}{l}\text { Statistical } \\
\text { significance }\end{array}$ & Remarks & \\
\hline \multicolumn{7}{|l|}{ Radiation } \\
\hline $\mathrm{X}$-rays & $8 \mathrm{~min}$ & $75-200 \mathrm{rad}$ & + & & $\begin{array}{c}\text { Chromosome breaks, } \\
\text { mostly at mitosis }\end{array}$ & Sax, 1938 \\
\hline $\mathrm{X}$-rays & $\sim 5 \mathrm{~min}$ & $77-416 \mathrm{rad}$ & + & $p<0.05$ & $\begin{array}{l}\text { Chromatid aberra- } \\
\text { tions in pollen } \\
\text { tubes and micro- } \\
\text { spores, and signif- }\end{array}$ & $\begin{array}{l}\text { Kirby-Smith } \\
\text { and } \\
\text { Daniels, } \\
1953\end{array}$ \\
\hline${ }^{60} \mathrm{Co} \gamma$-rays & $30 \mathrm{~min}$ & $100-400 \mathrm{rad}$ & + & $p<0.01$ & $\begin{array}{l}\text { icance measured } \\
\text { for coefficients in } \\
\text { exponential fit of } \\
\text { data }\end{array}$ & \\
\hline${ }^{32} \mathrm{P} \beta$-rays & $20 \mathrm{~min}$ & $100-400$ rep & + & $p<0.01$ & & \\
\hline${ }^{60} \mathrm{Co} \gamma$-rays & $16 d$ & $0.41 \mathrm{rad}$ & + & $p<0.05$ & $\begin{array}{l}\text { Micronuclei in micro- } \\
\text { spores }\end{array}$ & $\begin{array}{l}\text { Sparrow } \\
\text { and } \\
\text { Singleton, } \\
1953\end{array}$ \\
\hline $\begin{array}{l}\text { X-rays on } \\
\text { 5-FUdR } \\
\text { treated cells }\end{array}$ & $\begin{array}{l}36 \mathrm{~h} \\
5 \text {-FUdR } \\
+2 \text { min } \\
\text { X-rays }\end{array}$ & $\begin{array}{l}100 \mathrm{rad}+10^{6} \mathrm{M} \\
5 \text {-FUdR }\end{array}$ & + & $p<0.05$ & $\begin{array}{l}\text { Mitotic delay result- } \\
\text { ing in reduced } \\
\text { number of ex- } \\
\text { changes and chro- } \\
\text { matid breaks }\end{array}$ & $\begin{array}{c}\text { Rushton, } \\
1969\end{array}$ \\
\hline X-rays & Seconds & $20-40 \mathrm{rad}$ & + & & $\begin{array}{l}\text { Positive dose re- } \\
\text { sponse relation- } \\
\text { ship in } \mathrm{MCN}\end{array}$ & Ma, 1979a \\
\hline$X$-rays & Seconds & $10-58 \mathrm{rad}$ & + & & $\begin{array}{l}\text { Correlation coeffi- } \\
\text { cient for dose } \\
\text { response }=0.995\end{array}$ & $\begin{array}{c}\text { Ma et al., } \\
1980\end{array}$ \\
\hline $\begin{array}{l}\text { X-rays plus } \\
\text { tannic acids }\end{array}$ & $12 \mathrm{~h}$ & 35 rad $X$-rays & + & & $\begin{array}{l}\text { Synergistic inter- } \\
\text { action, positive } \\
\text { dose-response } \\
\text { relationship }\end{array}$ & $\begin{array}{l}\text { Krasmuller } \\
\text { et al., } \\
1992\end{array}$ \\
\hline Space flight & $\begin{array}{l}\text { In situ } \\
\text { exposure } \\
\text { in space } \\
\text { satellites }\end{array}$ & & + & & $\begin{array}{l}\text { Several developmen- } \\
\text { tal effects ob- } \\
\text { served in the } \\
\text { embryo sacs }\end{array}$ & $\begin{array}{l}\text { Marimuthu } \\
\text { et al., } \\
1972\end{array}$ \\
\hline Cosmic rays & $\begin{array}{l}\text { In situ } \\
\text { exposure } \\
\text { in space } \\
\text { satellites }\end{array}$ & & + & & $\begin{array}{l}\text { Unusual chromo- } \\
\text { some aberrations, } \\
\text { i.e., nonreciprocal } \\
\text { translocations and } \\
\text { spherical fragments }\end{array}$ & $\begin{array}{c}\text { Delone } \\
\text { et al., } \\
1986\end{array}$ \\
\hline
\end{tabular}

recessive pink color (Emmerling-Thiompson and Nawrocky, 1982; Mericle and Mericle, 1967; Mericle and Mericle, 1971; Nayar and Sparrow, 1967). Early studies with this sys- tem centered on the assessment of the genotoxic and cytotoxic effects of ionizing radiation and employed the meristematic cells of the stamen hairs of Tradescantia clone 02 as 
a higher organism surrogate for microbial cultures. In this assay, full growth of the hair was considered as equivalent to colony formation and stunted hairs as equivalent to nonsurvivors in cell cultures due to severe, highly deleterious or lethal events. In addition to mutation (color change) being used as an endpoint, genotoxic changes such as the expression of giant, twin, or triplet cells, branching of the hair and other growth anomalies were recorded along with loss of reproductive integrity as indicators of genotoxicity (Nayar and Sparrow, 1967).

The genetic basis for the expression of pink cells in the stamen hairs of Tradescantia clone 4430 was established by means of reciprocal test-crosses with the parental pink-and white-colored T. subacaulis Bush (Emmerling-Thompson and Nawrocky, 1980). Pink pigmentation was determined to depend on a pair of alleles at a single locus, with blue (B) being dominant to pink (b); and clone 4430 was shown to be homozygous dominant for the white locus. The identity of both blue and pink pigments of four different clones of Tradescantia have been determined microspectrophotometrically (Sanda-Kamigawara and Ichikawa, 1993).

Pink nutation as well as loss of reproductive integrity in the stamen hairs of several species and hybrids of Tradescantia (Ichikawa and Sparrow, 1967a; Ichikawa and Sparrow, 1967b; Ichikawa and Sparrow, 1968; Ichikawa and Sparrow, 1969; Ichikawa et al., 1969; Sparrow and Ichikawa, 1967) became important endpoints in the study of the genotoxic effects of radiation (Alvarez and Sparrow, 1965; Kappas et al., 1972; Nauman et al., 1976; Nauman et al., 1974; Sparrow et al., 1973; Underbrink et al., 1973a; Underbrink et al., 1971).

Sparrow and co-workers (1972) studied the effects of neutrons and X-rays in the Trad-SHM assay (clone 02), defining a linear dose-effect relation for both agents and a doubling dose as low as 1 rad for $\mathrm{X}$-rays.
The spontaneous mutation frequencies of several species and hybrids of Tradescantia were determined based on many years of experimentation at Brookhaven National Laboratory (Sparrow and Sparrow, 1976). Hybrids (i.e., clone 4430) and putative hybrids (i.e., clone 02) showed lower frequencies and a narrower variability in spontaneous mutation when compared with clones of pure species and were considered more suitable subjects for experimentation.

The effects of background radioactivity were studied during orbital flight (Sparrow et al., 1968) and by cultivating Tradescantia on monazite sand (Nayar et al., 1970). Mutation was found to increase in all exposed samples, and radionuclides absorbed into the plants were much more effective than external radiation alone. These results were later confirmed by exposing plants to soil samples drawn from the nuclear bomb experimental site at Bikini Island (Ichikawa and Ishii, 1991). Soil samples that caused significant increases in mutation frequency were shown to contain ${ }^{137} \mathrm{Cs}$ and ${ }^{60} \mathrm{Co}$, among other radionuclides. Other studies involving the absorption of radionuclides include tritiated chemicals (Nauman et al., 1979; Tano et al., 1984) and ${ }^{131}$ I (Tano and Yamaguchi, 1979).

The Trad-SHM assay was used in silu as a monitor for ionizing radiation in the vicinity of nuclear power plants in a large study carried out in Japan (Ichikawa, 1981). Significantly increased mutation frequencies were correlated with wind direction and operation periods of the nuclear facilities. CebulskaWasilewska (1992) observed an increase in the spontaneous mutation frequencies of Tradescantia correlated with the contamination caused in Cracow by the blowout of the nuclear reactor in Chernobyl (a 700-km distance). Similar increase in somatic mutation frequencies were also recorded in May to June 1986 in Japan (more than $8000 \mathrm{~km}$ distance) (Ichikawa et al., 1996). In this case, variations in spontaneous mutation rates in a 
10-year period (1982 10 1992) could always be correlated to temperature factors, but the significantly high mutation frequency in this particular period of 1986 could not. Exposure to radiation also enabled the standardization of the Trad-SHM assay as related to temperature variations (Nauman et al., 1977a; Nauman et al., 1977b), dose (Nauman et al., 1977c; Nauman et al., 1975), and other variables of the experimental conditions (Underbrink and Sparrow, 1974; Underbrink et al., 1975a; Underbrink et al., 1975b).

The applicability of the Trad-SHM assay 10 chemical mutagenesis studies was proposed by Underbrink et al. (1973b) and tested in a comparison of the effects of ionizing radiation and gaseous EMS and DBE (Nauman et al., 1976). The responses to chemical agents showed characteristics similar to X-rays (exponential rise followed by saturation in mulant cell frequencies), and clone 4430 was more sensitive than clone 02 . These results were later confirmed with a variety of chemicals and radionuclides (Tano, 1987; Tano, 1990; Tano and Yamaguchi, 1985). In these studies, mutagens were applied topically, direclly onto the inflorescences. Doses as low as 5 to $20 \mathrm{pg}$ for $N$-nitroso- $N$-methylurea and $N$-nitroso- $N$-ethylurea, and $100 \mathrm{pg}$ for EMS were effective and detectable in the Trad-SHM test. The detection limit for external radiation was below 1 rad.

This high sensitivity of the Trad-SHM assay to chemical mutagens was first shown after the accidental exposure of plants (clone (02) to fumes entering the air supply of a building at Brookhaven National Laboratory. A sudden increase in spontaneous mutation frequency raised the suspicion that led to the discovery of the contamination (Sparrow and Schairer, 1971). Additional studies with the Trad-SHM assay evaluating the mutagenesis of chemical agents involve maleic hydrazide (Gichner et al., 1982b), MMS, EMS, DMS (dimethyl sulfate) (Ichikawa et al., 1990; Ichikawa and Takahashi, 1978; Sanda-
Kamigawara et al., 1991), $\mathrm{N}$-nitroso compounds, and several organic solvents, among other agents, as well as evaluations of synergistic action between chemicals and between chemicals and radiation (Badaev et al., 1989; Gichner et al., 1994; Gichner et al., 1982a; Gichner et al., 1988; Ichikawa, 1992; Ichikawa et al., 1990; Ichikawa et al., 1993; Kuglik et al., 1994; Sanda-Kamigawara et al., 1991; Shima and Ichikawa, 1994; Shima and Ichikawa, 1995a; Shima and Ichikawa, 1995b; Veleminsky et al., 1987; Villalobos-Pietrini et al., 1986).

The Trad-SHM has been shown to be capable of activating promutagens into directacting mutagens (Gichner et al., 1980). Benzo$\alpha$-pyrene, atrazine, and several $N$-nitroso compounds were mutagenic when tested without prior treatment with microsomal fractions (Veleminsky and Gichner, 1988). Xiao and Ichikawa (1995, 1996) reported activation of maleic hydrazide ( $\mathrm{MH}$ ) into a mutagen by peroxidase, and showed that $\mathrm{MH}$ could act synergistically (Cebulska-Wasilewska et al., 1981 ) and antagonistically with $X$-rays when $\mathrm{X}$-rays were delivered before and after $\mathrm{MH}$ treatments, respectively. $\mathrm{X}$-rays suppressed the activation of $\mathrm{MH}$ in the latter case. A review of the mutagenicity of ionizing radiation and chemical agents in the Trad-SHM assay was presented by Ichikawa (1992).

Perhaps the most important contribution of the Trad-SHM assay was in the series of studies on atmospheric pollution carried out with a mobile laboratory (Schairer, 1979; Schairer and Sautkulis, 1982; Schairer et al., 1982; Schairer et al., 1979; Schairer et al., 1983). Air drawn from polluted sites around the U.S. induced higher mutation frequencies than filtered air samples from the same locations or air samples from the control site in the Grand Canyon. The mutagenicity of polluted atmospheres (Sparrow and Schairer, 1974) has been detected also in the vicinity of an oil refinery and petrochemical complex (Lower et al., 1983a), a lead smelter (Lower et al., 1978; Lower et al., 1983b), a pharma- 
ceutical factory (Cebulska-Wasilewska and Guminska, 1987), and a municipal waste incinerator (Ma, 1994b; Ma et al., 1993b; Ma et al., 1996).

The mutagenic effects of chemical smokes used by the U.S. Army were evaluated with the Trad-SHM assay. Positive responses were found for fogoil and tank diesel, as well as for their combination (Schaeffer et al., 1987). Ozone at concentrations occasionally found in polluted areas $(300$ to $800 \mathrm{ppb})$ was not mutagenic in the Trad-SHM assay (Gichner et al., 1992; Rodrigues et al., 1996), even though it had been reported positive at higher concentrations (Schairer, 1979). A review of the Trad-SHM as an assay for gaseous mutagens was presented under the U.S. EPA Gene-Tox Program (Van't Hof and Schairer, 1982).

In addition to studies of gaseous mutagens, the Trad-SHM assay has been used to assess the mutagenicity of aquatic environments (Lower et al., 1985; Tano, 1989). Episodes of mutagenicity in the water of a reservoir in Missouri were shown to be correlated with events facilitating the transfer of mutagens from the contaminated sediment to the water column (Lower et al., 1985). Grant et al. (1992) evaluated in situ the genotoxicity of the water in an area of Lake Superior in the vicinity of a pulp and paper mill, using the Trad-SHM, the TradMCN (micronuclei) and the $V$. faba chromosome aberration assays. Even though the Trad-SHM was sensitive enough to detect mutagenic effects, it was inferior to the other assays in terms of amenability for field manipulation. Remotely located field sites cause difficulties in cultivating the plants for the long ( $14 \mathrm{~d}$ ) recovery period required in this test.

There is a scarcity of information on the mutagenic effects of pesticides in the TradSHM assay (Mohammad and Ma, 1983). Tomkins and Grant (1972) studied the mutagenic effects of menazon (an $s$-triazine aphicide), metobromuron (substituted urea herbi- cide), and Daconil $2787^{\oplus}$ (chlorothalonil, chlorinated aromatic hydrocarbon fungicide) by wrapping the inflorescences of Tradescantia with cotton soaked in pesticide solutions ( $1500 \mathrm{ppm}$ ). No positive responses were found. The mutagenicity of the herbicide and growth regulator maleic hydrazide has been demonstrated (Gichner et al., 1982b; Xiao and Ichikawa, 1995; Xiao and Ichikawa, 1996). The benzimidazole-derived fungicide Benlate ${ }^{\text {fin }}$ (benomyl) was tested for mutagenicity with the Trad-SHM assay (clone KU 20) at doses used commonly in agriculture (0.5 to $4.0 \mathrm{~g} / \mathrm{l})$ (Sakamoto and Takahashi, 1981). Again, no positive responses were recorded. Contrasting with these negative results, seven out of nine insecticides were positive when tested with the Trad-SHM assay using clone 4430) (Huang and Chen, 1993a). Dichlorvos (0.1\%), omethoate $(0.04 \%)$, methamidophos $(9.05 \%)$, Meobal $^{\circledR}(3,4$-xylyl methylcarbamate $)(0.05 \%)$, mevinphos $(0.006 \%)$, Amobem ${ }^{\circledast}$ (chloramben, actually an herbicide) $(0.045 \%)$ and thiophanate-methyl $(0.07 \%)$ gave positive results, whereas trichlorfon $(0.1 \%)$ and $\mathrm{Bassa}^{\circledR}$ (2-sec-butylphenyl methylcarbamate) (0.02\% toxic) did not. Atrazine was reported mutagenic after chronic exposure (Schairer and Sautkulis, 1982), and cyanazine also has been reported to be mutagenic in the Trad-SHM system (Veleminsky and Gichner, 1988).

A summary of the results obtained with the Trad-SHM in the assessment of environmental mutagenesis is presented in Table 7.

\section{CONCLUSION}

A wealth of basic genetic and developmental information available on Tradescantia provides a solid framework in support of its use as a biomonitor in environmental genotoxicity assays (Ma and Grant, 1982). Micronuclei in the pollen mother cells are easily recognizable, permitting a low degree of uncertainty in scoring, and diminishing the subjectivity in the recognition of chromo- 
TABLE 7

Summary of Environmental Mutagenesis Results Obtained with the Stamen Hair Mutation Assay in Tradescantia (Trad-SHM)

\begin{tabular}{|c|c|c|c|c|c|c|}
\hline \multirow[b]{2}{*}{ Agent } & \multicolumn{3}{|c|}{ Dose range } & \multicolumn{2}{|c|}{ Result } & \multirow[b]{2}{*}{ Ret. } \\
\hline & $\begin{array}{l}\text { Exposure } \\
\text { time-max }\end{array}$ & Concentration & $+1-$ & $\begin{array}{l}\text { Statistical } \\
\text { significance }\end{array}$ & Remarks & \\
\hline \multicolumn{7}{|c|}{$\begin{array}{l}\text { Air pollution } \\
\text { In situ monitoring }\end{array}$} \\
\hline $\begin{array}{l}\text { Several pollut- } \\
\text { ed sites } \\
\text { throughout } \\
\text { the U.S. }\end{array}$ & $10 \mathrm{~d}$ & & + & $p<0.05$ & $\begin{array}{l}\text { Highest mutation } \\
\text { rates associated } \\
\text { with petroleum } \\
\text { processing }\end{array}$ & $\begin{array}{l}\text { Schairer, } \\
1979 ; \\
\text { Schairer } \\
\text { and } \\
\text { Sautkulis, } \\
1982 ; \\
\text { Schairer } \\
\text { et al., } \\
1982\end{array}$ \\
\hline Lead smelter & $\begin{array}{l}\text { Chronic } \\
\text { exposure }\end{array}$ & $\begin{array}{l}0.3-11 \mathrm{~km} \\
\text { from source }\end{array}$ & $+1-$ & $\rho<0.001$ & $\begin{array}{l}\text { No correlation oc- } \\
\text { curred between } \\
\text { mutation rate and } \\
\text { distance from the } \\
\text { smelter }\end{array}$ & $\begin{array}{l}\text { Lower et } \\
\text { al., } 1978 \text {; } \\
\text { Lower } \\
\text { et al., } \\
1983 \mathrm{~b}\end{array}$ \\
\hline Oil relinery & $\begin{array}{l}\text { Chronic } \\
\quad \text { exposure }\end{array}$ & $\begin{array}{l}100-500 \mathrm{~m} \\
\text { from source }\end{array}$ & + & $\rho<0.001$ & $\begin{array}{l}\text { All tests were statis- } \\
\text { tically significant } \\
\text { for one location in } \\
\text { Texas when com- } \\
\text { pared with the } \\
\text { green-house control }\end{array}$ & $\begin{array}{l}\text { Lower } \\
\text { et al., } \\
1983 a\end{array}$ \\
\hline $\begin{array}{l}\text { Landfill } \\
\text { gaseous } \\
\text { emissions }\end{array}$ & $4-6 \mathrm{~h}$ & & + & & $\begin{array}{l}\text { Positive responses } \\
\text { in } 7 \text { of } 13 \text { moni- } \\
\text { toring trips; gases } \\
\text { burned at emis- } \\
\text { sion source }\end{array}$ & $\begin{array}{l}\text { Ma et al., } \\
\text { 1993a }\end{array}$ \\
\hline $\begin{array}{l}\text { Municipal } \\
\text { incinerator }\end{array}$ & $4-6 h$ & & + & & $\begin{array}{l}\text { Positive results ob- } \\
\text { tained with stag- } \\
\text { nant atmosphere }\end{array}$ & $\begin{array}{l}\text { Ma et al., } \\
\text { 1993b }\end{array}$ \\
\hline $\begin{array}{l}\text { Chemical } \\
\text { smokes }\end{array}$ & $30 \mathrm{~min}$ & $\begin{array}{l}15-100 \mathrm{~m} \\
\text { from source }\end{array}$ & - & $p>0.9$ & & $\begin{array}{l}\text { Schaeffer } \\
\text { et al., } \\
1987\end{array}$ \\
\hline \multicolumn{7}{|c|}{ Selected gases in chambers } \\
\hline NO & $6 \mathrm{~h}$ & 250 ppm & + & $p<0.01$ & & $\begin{array}{l}\text { Schairer } \\
\quad \text { and } \\
\text { Sautkulis, } \\
1982 ; \\
\text { Van't Hof } \\
\text { and } \\
\text { Schairer, } \\
1982\end{array}$ \\
\hline $\mathrm{NO}_{2}$ & $6 \mathrm{~h}$ & 50 ppm & + & $p<0.05$ & & \\
\hline $\mathrm{SO}_{2}$ & $6 \mathrm{~h}$ & 40 ppm & + & $p<0.01$ & & \\
\hline $\mathrm{DBE}$ & $6 \mathrm{~h}$ & $1 \mathrm{ppm}$ & + & $p<0.01$ & & \\
\hline EMS & $6 \mathrm{~h}$ & $5 \mathrm{ppm}$ & + & $p<0.01$ & & \\
\hline Vinyl chloride & $6 \mathrm{~h}$ & 75 ppm & + & $p<0.02$ & & \\
\hline $\mathrm{O}_{3}$ & $6 \mathrm{~h}$ & 5 ppm & + & $p<0.02$ & & \\
\hline $\mathrm{O}_{3}$ & $11 \mathrm{~h} / \mathrm{d}$ & $800 \mathrm{ppb}$ & - & $p=0.68$ & & $\begin{array}{r}\text { Gichner et } \\
\text { al., } 1992\end{array}$ \\
\hline
\end{tabular}


TABLE 7 (continued)

Summary of Environmental Mutagenesis Results Obtained with the Stamen Hair Mutation Assay in Tradescantia (Trad-SHM)

\begin{tabular}{|c|c|c|c|c|c|c|}
\hline \multirow[b]{2}{*}{ Agent } & \multicolumn{3}{|c|}{ Dose range } & \multicolumn{2}{|c|}{ Result } & \multirow[b]{2}{*}{ Ref. } \\
\hline & $\begin{array}{l}\text { Exposure } \\
\text { time-max }\end{array}$ & Concentration & $+1-$ & $\begin{array}{l}\text { Statistical } \\
\text { significance }\end{array}$ & Remarks & \\
\hline $\mathrm{O}_{3}$ & $6 \mathrm{~h} / \mathrm{d}$ & $100 \mathrm{ppb}$ & - & $p>0.05$ & $\begin{array}{l}\text { Three days cumula- } \\
\text { tive exposure }\end{array}$ & $\begin{array}{c}\text { Rodrigues } \\
\text { et al., } \\
1992\end{array}$ \\
\hline \multicolumn{7}{|c|}{$\begin{array}{l}\text { Water pollution } \\
\text { In situ monitoring }\end{array}$} \\
\hline Lake water & $24 \mathrm{~h}$ & & - & $p<0.05$ & $\begin{array}{l}\text { Lake polluted by } \\
\text { pulp and paper } \\
\text { mill effluent } \\
\text { Results were } \\
\text { equivocal }\end{array}$ & $\begin{array}{l}\text { Grant et al. } \\
1992\end{array}$ \\
\hline $\begin{array}{l}\text { Bottom } \\
\text { sediment }\end{array}$ & $\begin{array}{l}\text { Chronic } \\
\text { exposure }\end{array}$ & & + & $p<0.005$ & $\begin{array}{l}\text { Mutation rates were } \\
\text { high in all 91-d } \\
\text { experimental } \\
\text { periods }\end{array}$ & $\begin{array}{l}\text { Lower et } \\
\text { al., } 1985\end{array}$ \\
\hline \multicolumn{7}{|c|}{ Selected chemicals in solution } \\
\hline $\begin{array}{l}\text { Benzo- } \alpha- \\
\text { pyrene }\end{array}$ & $24 \mathrm{~h}$ & $3.9 \times 10^{5} M$ & + & $p<0.01$ & & $\begin{array}{l}\text { Schairer } \\
\text { and } \\
\text { Sautkulis, } \\
\text { 1982; } \\
\text { Van't Hof } \\
\text { and } \\
\text { Schairer, } \\
1982\end{array}$ \\
\hline Calfeine & Chronic & $10^{-3} \mathrm{M}$ & - & $p>0.05$ & & \\
\hline $\mathrm{NaN}_{3}$ & $3 \mathrm{~h}$ & $10^{-3}$ & + & $p<0.01$ & & \\
\hline Benzidine & $24 \mathrm{~h}$ & $5.4 \times 10^{-7} M$ & + & $p<0.01$ & & \\
\hline EMS & $6 \mathrm{~h}$ & 10 ppm & + & & $\begin{array}{l}\text { Positive dose- } \\
\text { response relation- } \\
\text { ship from } 10 \text { to } \\
500 \mathrm{ppm}\end{array}$ & $\begin{array}{l}\text { Nauman } \\
\text { et al., } \\
1976\end{array}$ \\
\hline $\mathrm{DBE}$ & $6 \mathrm{~h}$ & $10 \mathrm{ppm}$ & & & Same as above & \\
\hline EMS & Acute & $100 \mathrm{ng}$ & + & $p>0.9$ & $\begin{array}{l}\text { Chemical solutions } \\
\text { applied directly } \\
\text { onto the } \\
\text { inflorescence }\end{array}$ & $\begin{array}{l}\text { Ichikawa et } \\
\text { al., 1990; } \\
\text { Ichikawa } \\
\text { and Tak- } \\
\text { ahashi, } \\
\text { 1978; } \\
\text { Sanda- } \\
\text { Kamiga- } \\
\text { wara et } \\
\text { al., 1991; } \\
\text { Tano, } \\
\text { 1987; } \\
\text { Tano, } \\
\text { 1990; } \\
\text { Tano and } \\
\text { Yamagu- } \\
\text { chi, 1985 }\end{array}$ \\
\hline $\begin{array}{l}N \text {-nitroso } \\
\text { compounds }\end{array}$ & Acute & $100 \mathrm{ng}$ & + & & & $\begin{array}{l}\text { Gichner et } \\
\text { al., } 1982 \mathrm{a}\end{array}$ \\
\hline
\end{tabular}


TABLE 7 (continued)

Summary of Environmental Mutagenesis Results Obtained with the Stamen Hair Mutation Assay in Tradescantia (Trad-SHM)

\begin{tabular}{|c|c|c|c|c|c|c|}
\hline \multirow[b]{2}{*}{ Agent } & \multicolumn{3}{|c|}{ Dose range } & \multicolumn{2}{|c|}{ Result } & \multirow[b]{2}{*}{ Ref. } \\
\hline & $\begin{array}{l}\text { Exposure } \\
\text { time-max }\end{array}$ & Concentration & +1 & $\begin{array}{l}\text { Statistical } \\
\text { significance }\end{array}$ & Remarks & \\
\hline $\begin{array}{l}\text { Maleic } \\
\text { hydrazide }\end{array}$ & Acute & & + & & $\begin{array}{l}\text { Synergism occurred } \\
\text { with X-rays deliv- } \\
\text { ered before } \mathrm{MH} \\
\text { treatment; and } \\
\text { suppression of } \\
\mathrm{MH} \text { effects by } \\
\text { X-rays applied } \\
\text { after } \mathrm{MH} \text { treatment }\end{array}$ & $\begin{array}{l}\text { Xiao and } \\
\text { Ichikawa, } \\
\text { 1995; } \\
\text { Xiao and } \\
\text { Ichikawa, } \\
1996\end{array}$ \\
\hline $\begin{array}{l}\text { N-nitroso } \\
\text { compounds } \\
\text { Pesticides }\end{array}$ & $24 h$ & Several & + & & & $\begin{array}{l}\text { Gichner et } \\
\text { al., 1982a }\end{array}$ \\
\hline Atrazine & Chronic & $0.045 \mathrm{mg}$ & & $\rho<0.01$ & $\begin{array}{l}\text { Dose applied per } \\
\text { pot }\end{array}$ & $\begin{array}{l}\text { Van't Hof } \\
\text { and } \\
\text { Schairer, } \\
1982\end{array}$ \\
\hline Menazon & $24 h$ & 1500 ppm & - & $p>0.05$ & $\begin{array}{l}\text { Inflorescence } \\
\text { wrapped with } \\
\text { pesticide-soaked } \\
\text { cotton }\end{array}$ & $\begin{array}{l}\text { Tomkins } \\
\text { and } \\
\text { Grant, } \\
1972\end{array}$ \\
\hline Metobromuron & & 1500 ppm & - & & & \\
\hline $\begin{array}{l}\text { Tetrachloro } \\
\text { isophthalo- } \\
\text { nitrile }\end{array}$ & & 1500 ppm & - & & & \\
\hline Benomyl & $2 \mathrm{~h}$ & $4 \mathrm{~g} / \mathrm{l}$ & - & $p>0.05$ & $\begin{array}{l}\text { Dose is equivalent to } \\
\text { recommended use }\end{array}$ & $\begin{array}{l}\text { Sakamoto } \\
\text { and } \\
\text { Tak- } \\
\text { ahashi, } \\
1981\end{array}$ \\
\hline $\begin{array}{l}\text { Nine } \\
\text { insecticides }\end{array}$ & & Several & $+1-$ & & $\begin{array}{l}\text { Positive responses } \\
\text { in seven of nine } \\
\text { compounds }\end{array}$ & $\begin{array}{l}\text { Huang } \\
\text { and } \\
\text { Chen, } \\
\text { 1993a }\end{array}$ \\
\hline \multicolumn{7}{|l|}{ Radiation } \\
\hline${ }^{60} \mathrm{Co} \gamma$-rays & $16 \mathrm{~h}$ & $500 \mathrm{R}$ & + & & $\begin{array}{l}\text { Mutation frequencies } \\
\text { decreased above } \\
300 \mathrm{~A}\end{array}$ & $\begin{array}{l}\text { Nayar and } \\
\text { Sparrow, } \\
1967\end{array}$ \\
\hline Monazite sand & Chronic & $1.3 \mathrm{mR} / \mathrm{h}$ & + & $p<0.05$ & & $\begin{array}{l}\text { Nayer et } \\
\text { al., } 1970\end{array}$ \\
\hline X-rays & mins & $160 \mathrm{R}$ & + & & $\begin{array}{l}\text { Positive dose- } \\
\text { response relation- } \\
\text { ships with doses } \\
\text { from } 10 \text { to } 160 \mathrm{rad}\end{array}$ & $\begin{array}{r}\text { Nauman et } \\
\text { al., } 1976\end{array}$ \\
\hline$X$-rays & mins & $160 \mathrm{R}$ & + & $p<0.01$ & $\begin{array}{l}\text { Positive dose- } \\
\text { response relation- } \\
\text { ships with doses } \\
\text { from } 0.25 \text { to } 5 \mathrm{rad}\end{array}$ & $\begin{array}{l}\text { Sparrow et } \\
\text { al., } 1972\end{array}$ \\
\hline Neutrons & mins & $10 R$ & + & $p<0.01$ & $\begin{array}{l}\text { Positive dose- } \\
\text { response relation- } \\
\text { ships with doses } \\
0.01 \text { to } 8 \text { rad }\end{array}$ & \\
\hline
\end{tabular}


TABLE 7 (continued)

Summary of Environmental Mutagenesis Results Obtained with the Stamen Hair Mutation Assay in Tradescantia (Trad-SHM)

\begin{tabular}{|c|c|c|c|c|c|c|}
\hline \multirow[b]{2}{*}{ Agent } & \multicolumn{3}{|c|}{ Dose range } & \multicolumn{2}{|r|}{ Result } & \multirow[b]{2}{*}{ Ref. } \\
\hline & $\begin{array}{l}\text { Exposure } \\
\text { time-max }\end{array}$ & Concentration & $+1-$ & $\begin{array}{l}\text { Statistical } \\
\text { significance }\end{array}$ & Remarks & \\
\hline $\begin{array}{l}\text { Internal } \\
\text { radiation }\end{array}$ & Acute & $100 \mathrm{nCi}$ & + & & $\begin{array}{l}\text { Tritium-labeled com- } \\
\text { pounds and }{ }^{131} \text {; } \\
\text { positive dose- } \\
\text { response relation- } \\
\text { ships occurred }\end{array}$ & Tano, 1987 \\
\hline In situ & & & & & & \\
\hline $\begin{array}{l}\text { exposure to } \\
\text { nuclear } \\
\text { power } \\
\text { plants }\end{array}$ & Chronic & & + & $p<0.05$ & $\begin{array}{l}\text { Significant increases } \\
\text { in mutation rates } \\
\text { were correlated } \\
\text { with operation } \\
\text { plants and wind } \\
\text { direction }\end{array}$ & $\begin{array}{c}\text { Ichikawa, } \\
1981\end{array}$ \\
\hline $\begin{array}{l}\text { Bikini Island } \\
\text { soils }\end{array}$ & $76 d$ & $150 \mu \mathrm{R} / \mathrm{h}$ & + & $p<0.01$ & $\begin{array}{l}\text { Main radionuclides } \\
\text { were }{ }^{137} \mathrm{Cs} \text { and } \\
{ }^{60} \mathrm{Co}\end{array}$ & $\begin{array}{l}\text { Ichikawa, } \\
\text { and } \\
\text { Ishii, } \\
1991\end{array}$ \\
\hline $\begin{array}{l}\text { In situ } \\
\text { exposure } \\
\text { to contam- } \\
\text { inated } \\
\text { atmosphere }\end{array}$ & Chronic & & + & $p<0.05$ & $\begin{array}{l}\text { Shortly after the } \\
\text { Chernobyl acci- } \\
\text { dent; plants ex- } \\
\text { posed in Cracow, } \\
700 \mathrm{~km} \text { from the } \\
\text { radiation source }\end{array}$ & $\begin{array}{l}\text { Cebulska- } \\
\text { Wasilew- } \\
\text { ska, } 1992\end{array}$ \\
\hline $\begin{array}{l}\text { In situ } \\
\text { exposure } \\
\text { to contam- } \\
\text { inated } \\
\text { atmosphere }\end{array}$ & Chronic & & + & $p<0.05$ & $\begin{array}{l}\text { Shortly after the } \\
\text { Chernobyl acci- } \\
\text { dent; plants ex- } \\
\text { posed in Japan, } \\
8000 \mathrm{~km} \text { from the } \\
\text { radiation source }\end{array}$ & $\begin{array}{l}\text { Ichikawa, } \\
\text { et al., } \\
1996\end{array}$ \\
\hline
\end{tabular}

somal breakage, while the induction of pink mutations in the stamen hairs provide a sensitive somatic indicator of mutagenesis. Additionally, the Tradescantia assays have proven to be suitable for studies on synergism between chemicals and between chemicals and other genotoxic agents such as radiation, a valuable property for the assessment of genotoxic risks in complex environmental situations (Shima and Ichikawa, 1995b).

Grant (1994) assessed the present status of higher plant bioassays for the detection of environmental mutagens, stressing the advantages of plant systems with regard to the possibility of performing in situ evaluations. In a recent study sponsored by the International Programme on Chemical Safety the utility of the two Tradescantia bioassays discussed here (along with three other plant bioassays) was evaluated with four known genotoxic chemicals (Grant and Salamone, 1994) in five different laboratories (Sandhu et al., 1994a; Sandhu et al., 1994b). The results obtained in this study substantiated the Trad-SHM assay as a reliable system for screening chemicals for their mutagenicity (Ma et al., 1994a). Regarding the Trad-MCN assay, even though the results for the four 
chemicals tested were not identical, there was good agreement among all laboratories, suggesting that the Trad-MCN assay is a reliable short-term bioassay for clastogens ( $\mathrm{Ma}$ et al., 1994b), and as has been reviewed in the present literature survey it is specially appropriate for the in situ monitoring of genotoxic chemicals.

In conclusion, the studies reviewed here demonstrate that Tradescantia plants, particularly the Trad-MCN and Trad-SHM assays, provide a very sensitive, easily manipulated system for the study of genotoxicity, especially under the in situ conditions indispensable for environmental studies.

\section{REFERENCES}

Ahmed, M. and Grant, W. F., 1972a. Cytological effects of the mercurial fungicide Panogen 15 on Tradescantia and Vicia faba root tips. Mutat. Res., 14: 391-396.

Ahmed, M. and Grant, W. F., 1972b. Cytological effects of the pesticides phosdrin and bladex on Tradescantia and Vicia faba. Can. J. Genet. Cytol., 14: 157-165.

Alvarez, M. R. and Sparrow, A. H., 1965. Comparison of reproductive integrity in the stamen hair and root meristem of Tradescantia paludosa following acute gamma irradiation. Radiat. Bot., 5: 423-430.

Anderson, V. and Ma, T. H., 1981. Micronuclei induced by internal beta irradiation from incorporated phosphorus-32 in Tradescantia pollen mother cells. Environ. Mutagen., 3: 398-399.

Anderson, V. and Ma, T. H., 1982. Micronuclei induced by low-dose cobalt- 60 gamma-irradiation in Tradescantia pollen mother cells. Environ. Mutagen., 4: 348.

Badaev, S. A., Gichner, T., Pospisil, F., and Veleminsky, J., 1989. Humic acids inhibit the formation but not the mutagenicity of $N$-methylN-nitrosourea. Mutat. Res., 210: 9-13.

Baud-Grasset, F., Baud-Grasset, S., Bifulco, J. M., Meier, J. M., and Ma, T. H., 1993a. Tradescantia micronucleus test on the genotoxicity of
PAH-contaminated soil after fungal treatment. In: Ecotoxicology and Environmental Chemistry - A Global Perspective. Abstracts: pp. 303. Society of Environmental Toxicology and Chemistry, Lisbon, Portugal.

Baud-Grasset, S., Baud-Grasset, F., Bifulco, J. M., Meier, J. R., and Ma, T. H., 1993b. Reduction of genotoxicity of a creosote-contaminated soil after fungal treatment determined by the Tradescantia micronucleus test. Mutat. Res., 303: $77-82$.

Cebulska-Wasilewska, A., 1992. Tradescantia stamen-hair mutation bioassay on the mutagenicity of radioisotope-contaminated air following the Chernobyl nuclear accident and I year later. Mutat. Res., 270: 23-29.

Cebulska-Wasilewska, A. and Guminska, M., 1987. The application of somatic mutation frequency in Tradescantia to measurements of mutagenic activity of polluted air. Folia. Med. Cracov., 28: 131-138.

Cebulska-Wasilewska, A., Leenhouts, H. P., and Chadwick, K. H., 1981. Synergism between EMS and X-rays for the induction of somatic mutations in Tradescantia. Int. J. Radiat. Biol., 40: $163-173$.

Chen, D., 1982. A preliminary observation on the effect of vitamin $\mathrm{C}$ and sodium selenate on the formation of Tradescantia MCN in polluted seawater. J. Shandong Coll. Oceanol., 12: 5556.

Chen, D., Dai, H., and Yang, Z. 1983. Tradescantiamicronucleus tests on sea water contaminated by oil spill. Environ. Pollut. Protect., 2: 39-40.

Chen, D. and Fang, T., 1981. A preliminary study on the use of Tradescantia micronucleus technique in monitoring marine pollution. J. Shandong Coll. Oceanol., 11: 81-85.

Chen, D. and Guan, H., 1988. Preliminary study on the genotoxic effect of the new medicine PSS (diester sodium alginate). J. Ocean Univ. Qingdao., 18: 48 51.

Chen, D., Ho, J., Xiang, D., and Fang, T., 1984. A comparative study on the COD index of the wastewater from factories in Qingdao, and the effect of the wastewater on micronuclei frequencies in Tradescantia. Environ. Sci. China. 4: $38-41$. 
Chen, D., Li, C., and Han, B., 1988. Application of Tradescantia-micronucleus (Trad-MCN) technique to study the clastogenicity of heavy metals before and after decontamination with marine yeast. Acta Sci. Circum., 8: 79-83.

Chen, D., Wang, Y., and Xing, L., 1989. A preliminary observation of the effect of wastewater from the electric power plants along the sea shore on some marine species and Tradescantia. Marine Environ. Sci., 8: 27-32.

Chen, D. and Xiang, D., 1983. Preliminary results of Tradescantia-micronucleus tests on the wastewater samples from several industrial factories in Qingdao. J. Environ. Sci., 4: 45-47.

Chen. D. and Zheng, D., 1982. Tradescantia-micronucleus tests on water samples from several seashore areas of Qingdao and Jiaozhouwan. $J$. Environ. Sci., 3: 35-37.

Chen, D. and Zhou, F., 1985. A comparative study on the sensitivity of two different species of Tradescantia to polluted sea water. Acta Oceanol. Sin., 7: 656-660).

Countryman, P. I. and Headdle, I. A., 1976. The production of micronuclei from chromosome aberrations in irradiated cultures of human lymphocytes. Mutat. Res., 41: 321-332.

Delone, N. L., Antipov, V. V., and Parfenov, G. P., 1986. New type of chromosomal mutation observed in Tradescantia paludosa microspores during experiments in space satellites. Dokl. Akad. Nauk. Sssrr. 290: 979-981.

Emmerling-Thompson, M. and Nawrocky, M. M., 1980. Genetic basis for using Tradescantia clone 4430 as an environmental monitor of mutagens. J. Hered., 71: 261-265.

Emmerling-Thompson, M. and Nawrocky, M. M., 1982. Evidence of gametic mutation for flower color in Tradescamia. Environ. Exp. Bot. 22: $403-408$.

Fang, T., 1981a. A prelimirary study on the use of tradescantia-micronucleus technique in monitoring mutagens in sea water. J. Shandong Coll. Oceanol., 11: 74-79.

Fang, T., 198lb. A report on the studies of effects of environmental pollutants on chromosomes - a Sino-American collaborated research project 1980) II. Tradescantia-micronucleus bioas- say on environmental mutagens in the air and water samples from some industrial areas of Qingdao, PRC and on the pesticide DI)V. $J$. Shandong Coll. Oceanol., 11: 0-11

Gichner, T., Langebartels, C., and Sandermann, H., Jr., 1992. Ozone is not mulagenic in the Tradescantia and tobacco mutagenicity assays. Mutat. Res., 281: 203-206.

Gichner, T., Lopez, G. C., Wagner, E. I)., and Plewa, M. J., 1994. Induction of somatic mutations in Tradescantia clone 4430 by three phenylenediamine isomers and the antimutagenic mechanisms of diethyldithiocarbamate and ammonium meta-vanadate. Mutat. Res., 306: 165 172.

Gichner, T., Veleminsky, J., and Pankova, K., 1982a. Differential response to three alkylating nitrosocompounds and three agricultural chemicals in the Salmonella (Ames) and in the Tradescantia. Arabidopsis and harley mutagenicity assays. Biol. Zbl., 101: 375-383.

Gichner, T., Veleminsky, J., and Pokorny, V., 1982b. Somatic mutation induced by maleic hydrazide and its potassium and diethylamine salts in the Tradescantia mutation assay. Mutat. Res., 103: 289-293.

Gichner, T., Veleminsky, J., and Ricger, R. 1988 Antimutagenic effects of diethyldithiocarbamale towards maleic hydrazide and $\mathrm{N}$-nitrosodiethylamine-induced mutagenicity in the Tradescantia mutagenicity assay. Biol. Plamt., 30:14-19

Gichner, T., Veleminsky, J., and Underhrink. A. (i., 1980. Induction of somatic mulations by the promutagen dimethyl nitrosamine in hairs of Tradescamtia stamen. Mutat. Res., 78: 381-384.

Gill, B. S. and Sandhu, S. S., 1992. Application of the Tradescantia micronucleus assay for the genetic evaluation of chemical mixtures in soil and aqueous media. Mufat. Res., 270): 65-69.

Grant, W. F., 1982. Cytogenetic studies of agricultural chemicals in plants. In: Genetic Toxicology: An Agricultural Perspective. Basic Life Sciences. pp. 353-378. Fleck, R. ^. and Hollaender, А., Eds., Plenum Press, New York.

Grant, W. F., 1994. The present status of higher plant bioassay for the detection of environmental mutagens. Mutat. Res., 310: 175-185. 


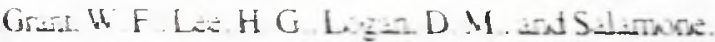

M. F., 1992. Trie use of Tradescantla and licia faba bicsassays ior ite in siar detection of mutagens in an aquatic environment. Mutat. Res., 270: 53-64.

Grant, W. F, and Salamone, M. F., 1994. Comparative mutagenicity of chemicals selected for test in the International Program on Chemical Safely's collaborative study on plant systems for the detection of environmental mutagens. Mutat. Res., 310: 187-209

Haider, T., Knasmuller, S., Kundi, M., and Haider, M., 1994. Clastogenic effects of radiofrequency radiations on chromosomes of Tradescantia. Mutat. Res., 324: 65-68.

Harris, M. M. and Ma, T. H., 1983. Tradescantiamicronucleus test on the mutagenicity of air freshners. Environ. Mutagen., 4: 65.

Helma, C., Knasmuller, S., Haider, T., and SchulteHermann, R., 1992. The use of the Tradescantiamicronucleus test to investigate the effect of activated carbon filtration and UV-irradiation on the mutagenicity of ground water contaminated by hazardous waste landfill. In: XXIII European Environmental Mutagen Society Meeting.

Helma, C., Knasmuller, S., Sanyal, R., Sommer, R., and Schulteherman, R., 1993. The effect of UV irradiation on the genotoxicity of contaminated groundwater detected by the Tradescantia micronucleus test, In Ecotoxicology and Environmental Chemistry - A Global Perspective. Abstracts: pp. 303. Sociely of Environmental Toxicology and Chemistry, Lisbon, Portugal.

Helma, C., Knasmuller, S., Schulte-Hermann, R., and Ma, T. H., 1994a. Clastogenicity of two water chlorination byproducts in the Tradescantiamicronucleus assay. Environ. Mol. Mutagen., 23 (Suppl. 23): 25.

Helma, C., Kronberg, L., Ma, T. H., and Knasmuller, S. 1995. Genotoxic effects of the chlorinated hydroxyfuranones 3-chloro-4-(dichloromethyl)5-hydroxy-2[5H]-furanone and 3,4-dichloro-5hydroxy-2|5H|-furanone in Tradescantia micronucleus assays. Mutat. Res., 346: 181186.

Helma, C., Sommer, R., Schulte-Hermann, R. and Knasmuller, S. 1994b. Enhanced clastogenicity of contaminated groundwater following UV

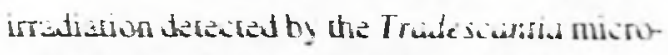
nucleus assay. Mutat. Res. 323: 93-98

Ho, J., Zhou, R. and Fang, T., 1983. Tradescantiamicronucleus tests on fluoride contaminated soil. In: 5th Annual Meeting of the Chinese Soil Science Society - Chinese Soil Utilization and Conservation, 2: pp. 325-326.

Hopke, P. K., Plewa, M. J., Johnston, J. B., Weaver, D., Wood, S. G., Larson, R. A., and Hinesly, T., 1982. Multitechnique screening of Chicago municipal sewage sludge for mutagenic activity. Environ. Sci. Technol., 16: 140-147.

Huang, N. and Chen, R., 1993a. The report of using Tradescantia Stamen Hair mutation to test 9 insecticides. Environ. Mol. Matagen., 21 (suppl. 22): 30 .

Huang, N. and Chen, R., 1993b. Tradescantia micronucleus (Trad-MCN) test on two agents used in fruit storage. Environ. Mol. Mutagen., 21 (suppl. 22): 30 .

Huang, N. and Chen, R. 1993c. Use of Tradescantia micronucleus assay in detecting the mutagenicity of two agents used in storing fresh fruit, In Ecotoxicology and Environmental Chemistry - A Global Perspective. Abstracts: pp. 302. Sociely of Environmental Toxicology and Chemistry, Lisbon, Portugal.

Ichikawa, S., 1981. In situ monitoring with Tradescantia around nuclear power plants. Environ. Health Persp., 37: 145-164.

Ichikawa, S., 1992. Tradescantia stamen-hair system as an excellent botanical tester of mutagenicity: its response to ionizing radiations and chemical mutagens, and some synergistic effects found. Mutat. Res., 270: 3-22.

Ichikawa, S. and Ishii, C., 1991. Somatic mutation frequencies in the stamen hairs of Tradescantia grown in soil samples from the Bikini Island. Jpn. J. Genet., 66: 27-40.

Ichikawa, S., Kanai, H., and Harada, H. 1990. Somatic mutation frequencies in Tradescantia stamen hairs treated with aqueous solutions of ethyl methanesulfonate and methyl methanesulfonate. Jpn. J. Genet., 65: 309.

Ichikawa, S., Nakano, A., Kenmochi, M., Yamamoto, I., Murai, M., Takahashi, E., Yamaguchi, A., Watanabe, K., Tomiyama, M., Sugiyama, K., 
Yogo, A., Yazaki, T., Okomura, M., Shima, N., Satoh, M., Yoshimoto, M., and Xiao, L. Z., 1996. Yearly variation of spontaneous somatic mutation frequency in the stamen hairs of Tradescantia clone KU 9 grown outdoors, which showed a significant increase after the Chernobyl accident. Mutat. Res., 349: 249-259.

lchikawa, S. and Sparrow, A. H., 1967a. Radiationinduced loss of reproductive integrity in the stamen hair of Tradescantia blossfeldians Mildbr., a 12-ploid species. Radiat. Bot., 7: 333-345.

Ichikawa, S. and Sparrow, A. H., 1967b. Radiationinduced loss of reproductive integrity in the stamen hairs of a polyploid series of Tradescantia species. Radiat. Bot., 7: 429-441.

Ichikawa, S. and Sparrow, A. H., 1968. The use of induced somatic mutations to study cell division rates in irradiated stamen hairs of Tradescantia virginiana L. Jpn. J. Genet., 43: 57-63.

Ichikawa, S. and Sparrow, A. H., 1969. Analyses of radiation-induced loss of reproductive integrity in Tradescantia stamen hairs, an essentially single meristematic cell system. Jpn. J. Genet., 44: $23-24$

Ichikawa, S., Sparrow, A. H., and Thompson, K. H., 1969. Morphologically abnormal cells, somatic mutation and loss of reproductive integrity in irradiated Tradescantia stamen hairs. Radiat. Bot., 9: 195-211.

Ichikawa, S. and Takahashi, C. S., 1978. Somatic mutations in Tradescantia stamen hairs exposed to ethyl methanesulfonate. Environ. Exp. Bot., 18: 19-25.

Ichikawa, S., Yamaguchi, A. and Okumura, M., 1993. Synergistic effects of methyl methanesulfonate and X-rays in inducing somatic mutations in the stamen hairs of Tradescantia clones, KU 27 and BNL 4430. Jpn. J. Genet., 68: 277-292.

Jenssen, D. and Ramel, C., 1976. Dose response at low doses of $\mathrm{X}$-irradiation and MMS on the induction of micronuclei in mouse erythroblasts. Mutat. Res., 41: 311-320.

Johnston, J. B. and Hopke, P. K., 1980. Estimation of the weight-dependent probability of detecting a mutagen with the Ames assay. Environ. Mutagen., 2: 419-424.

Kappas, A., Sparrow, A. H., and Nawrocky, M. M., 1972. Relative biological effectiveness (RBE) of 0.43-Mev neutrons and 250-Kvp X-rays for somatic aberrations in Tradescantia subacaulis Bush. Radiat. Bot., 12: 271-281

Khan, S. H. and Ma, T. H., 1974. Hydroxyureaenhanced chromatid aberrations in Tradescantia (paludosa) pollen tubes and seasonal variation of aberration rates. Mutat. Res., 25: 33-38

Kirby-Smith, J. S. and Daniels, D. S., 1953. The relative effects of $\mathrm{X}$-rays, gamma rays and beta rays on chromosomal breakage in Tradescantia. Genetics, 38: 375-388.

Knasmuller, S., Kim, T. W. and Ma, T. H., 1992. Synergistic effect between tannic acid and X-rays detected by the Tradescantia micronucleus assay. Mutat. Res., 270: 31-37.

Knasmuller, S. and Ma, T. H., 1992. Die Verwendung von Tradescantia sum Nachweis erbgutschadigender Chemikalien in der Umwelt. In: Moglichkeiten und Grenzen der Reduktion von Tierversuchen. pp. 127-132. Schoffl, H., Schulte-Hermann, R. and Tritthart, H. A., Eds., Springer-Verlag, Wein.

Kuglik, P., Veselska, R., and Relichova, J., 1994. Sensitivity of plant cytogenetic and genetic short term assays for evaluating genetic damage induced by chemical mutagens. Cell Biol. Int., 18: 543

L'Hermite, P. and Dehandtschttler, J., Eds. (1980) Copper in Animal Wastes and Sewage Sludge, D. Reidel Publ. Co., London. 378 p.

Lo, M., 1985. Tradescantia-micronucleus tests on drinking water. Sichuan Environ., 4: 45-47.

Lower, W. R., Drobney, V. K., Aholt, B. J., and Politte, R., 1983a. Mutagenicity of the environments in the vicinity of an oil refinery and a petrochemical complex. Terat. Carcin. Mutag., 3: $65-7.3$

Lower, W. K., Rose, P. S., and Drobney, V. K., 1978. In situ mutagenic and other effects associated with lead smelting. Mutat. Res., 54: 8393.

Lower, W. R., Thompson, W. A., Drobney, V. K., and Yanders, A. F., 1983b. Mutagenicity in the vicinity of a lead smelter. Terat. Carcin. Mutag., 3: 231-253.

Lower, W. R., Underbrink, A. G., Yanders, A. F., Roberts, K., Ranney, T. K., Lombard, G. T., Hemphill, D. D., and Clevenger, T., 1984. New 
methodology for assessing mutagenicity of water and water-related sediments. In: Second International Conference on Groundwater Quality Research. pp. 194-196. Oklahoma State University Printing Services Publishers, Stillwell, OK.

Lower, W. R., Yanders, A. F., Marrero, T. R., Underbrink, A. G., Drobney, V. K., and Collins, M. D., 1985. Mutagenicity of bottom sediment from a water reservoir. Environ. Toxicol. Chem., 4: 13-19.

Ma, T. H., 1967. Thin layer lactose-agar for pollen tube culture of Tradescantia to enhance planar distribution chromosomes. Stain Tech., 42: 285291.

Ma, T. 11., 1979a. Micronuclei induced by X-rays and chemical mulagens in meiotic pollen mother cells of Tradescantia - a promising mutagen test system. Mutat. Res., 64: 307-313.

Ma, T. H., 1979b. Tradescantia micronuclei (TradMCN) test for environmental clastogens. In: In Vitro Toxicity Testing of Environmental Agents. Current and Future Possibilities. P'art A: Survey of Test Systems. pp. 191-214. Kolber, A. R., Wong, T. K., Grant, L. D., DeWoskin, R. S., and Hughes, T. J., Eds., Plenum Press, New York.

Ma, T. H., 1981a. Tradescantia micronucleus bioassay and pollen tube chromatid aberration test Ior in silu monitoring and mulagen screening. Environ. Heallh Persp., 37: 85-90.

Ma, T. H., 1981b. Tradescantia-MCN-in-tetrad mutagen test for on site monitoring and further validation. Report, US EPA, 60()/SI-81-019.

Ma, T. H., 1981 c. Tradescantia-micronucleus (Trad$\mathrm{MCN}$ ) test for environmental clastogens. J. Shandong Coll. Oceanol., 11: 65-73.

Ma, T. H., 1982. Tradescantia cytogenetic tests (roottip mitosis, pollen mitosis, pollen mother-cell meiosis). A report of the U. S. Environmental Protection Agency Gene-Tox Program. Mutat. Res., 99: 293-302.

Ma, T. H., 1989. In situ monitoring of environmental clastogens using Tradescantia-micronucleus bioassay. In: First Symposium on in situ evaluation of biological hazards of environmental pollutants. Chapel Hill, NC.

Ma, T. H., 1990a. A dual biomonitoring system for the genotoxicity of air and water at the site of hazardous waste mixtures. In: Sixth Annual Waste Testing and Quality Assurance Symposium. 11: pp. 428-436. Washington, DC.

Ma, T. H., 1990b. Tradescantia microntucleas test on clastogens and in situ monitoring. In: Mutation and the Environment. Progress in Clinical and Biological Research. pp. 83 -90. Mendelsohn, M. L. and Albertini, R. J., Eds., Wiley-Liss, New York.

Ma, T. H., 1993. Detection of genotoxicity of water and air pollutants using Tradescantia (spiderwort) plants. In: Use of Biomarkers in Assessing Health and Environmental Impacts of Chemical Pollutants. pp. 247-253. Travis, C. C., Ed., Plenum Press, New York.

Ma, T. H., 1994a. Application of quick and simple plant bioassays to assess the genotoxicity of environmental pollutants - detection of potential health hazards in air, water and soil contaminants. In: EUROTOX Congress. pp. 42-43. Springer, Basel, Switzerland.

Ma, T. H., 1994b. Landfill or incineration - - which is the better way to treat our solid wastes? Environ. Mol. Mutagen., 23 (Suppl. 23): 40.

Ma, T. H., Anderson, V. A., and Ahmed, 1., 1982a. Environmental clastogens detected by meiotic pollen mother cells of Tradescantia. In: Genotoxic Effects of Airborne Agents. Environmental Science Research. pp. 141-157. Tice, R. R., Costa, D. L., and Schaich, K. M., Eds., Plenum Press, New York.

Ma, T. H., Anderson, V. A., Harris, M. M., and Bare, J. L., 1983a. Tradescantia-micronucleus (Trad-MCN) test on the genotoxicity of malathion. Environ. Mutagen., 5: 127-137.

Ma, T. H., Anderson, V. A., Harris, M. M., Neas, R. E., and Lee, T. S. 1985. Mutagenicity of drinking water detected by the Tradescantia micronucleus test. Can. J. Genet. Cytol., 27: 143-150.

Ma, T. H., Anderson, V. A., and Sandhu, S. S., 1982b. A preliminary study of the clastogenic effects of diesel exhaust fumes using Tradescantia-micronucleus bioassay. In: Short-Term Bioassays in the Analysis of Complex Environmental Mixtures II. pp. 352-358. Waters, Sandhu, Huisingh, Claxton, and Nesnow, Eds., Plenum Press, New York. 
Ma, T. H. and Cabrera, G. L., 1986. Desarrollo y aplicacion de un bioensayo simple y rapido para mutagenesis ambiental. In: II Semana de la Ecologia y Prolection del Ambiente. pp. 130 132. Universidade Autonoma de Queretaro, Mexico.

Ma, T. H., Cabrera, G. L., Cebulska-Wasilewska, A., Chen, R., Loarca, F., Vandenberg, A. L., and Salamone, M. F., 1994a. Tradescantia stamen hair mutation bioassay. Mutat. Res., 310: $211-220$.

Ma, T. H., Cabrera, G. L., Chen, R., Gill, B. S., Sandhu, S. S., Vandenberg, A. L., and Salamone, M. F., 1994b. Tradescantia micronucleus bioassay. Mutat. Res., 310: 221-230.

Ma, T. H., Fang, T., Ho, J., Chen, D., Zhou, R., Lin, G., Dai, J., and Li, J., 1982c. Extraordinary high micronucleus frequency induced by $\mathrm{X}$-rays in a special clone of Tradescantia reflexa. Mutat. Res., 104: 101-103.

Ma, T. H. and Grant, W. F., 1982. The Tradescantias - adventurous plants. Herbarist., 48: 36-44.

Ma, T. H. and Harris, M., 1987a. Tradescantia micronucleus (Trad-MCN) assay - a potential indoor pollution monitor. Environ. Mutagen., 9 (Suppl. 8): 65

Ma, T. H. and Harris, M. M., 1985. In situ monitoring of environmental mutagens. In: Hazard Assessment of Chemicals, Current Developments. pp. $77-106$.

Ma, T. H. and Harris, M. M., 1987b. Tradescantia micronucleus (Trad-MCN) bioassay - a promising indoor air pollution monitoring system. In: 4th International Conference on Indoor Air Quality and Climate. 1: pp. 243-247. Institute for Water, Soil, and Air Hygiene, Berlin (West).

Ma, T. H., Harris, M. M., Anderson, V. A., Ahmed, I., Mohammad, K., Bare, J. L., and Lin, G., 1984. 'Tradescantia-micronucleus (Trad-MCN) tests on 140 health-related agents. Mutat. Res., 138: $157-167$.

Ma, T. H., Isbandi, D., Khan, S. H., and Tseng, Y., S., 1973. Low level of SO2 (sulfur dioxide)-enhanced chromatid aberrations in Tradescantia (paludosa) pollen tubes and seasonal variation of the aberration rates. Mutat. Kes., 21: $93-100$.
Ma, T. H. and Khan, S. H., 1976. Pollen mitosis and pollen tube growth inhibition by $\mathrm{SO} 2$ (sulfur dioxide) in cultured pollen tubes of Tradescantia. Environ. Res., 12: 144 149.

Ma, T. H., Kontos, G. J., Jr., and Anderson, V. A., 1980. Stage sensitivity and dose response of meiotic chromosomes of pollen mother cells of Tradescantia to X-rays. Envirm. Exp. Bot., 20: $169-174$.

Ma, T. H., Lower, W. R., Harris, F. D., Poku, J., Anderson, V. A., Harris, M. M., and Bare, I. I.. 1983b. Evaluation by the Tradescantia-micronucleus tests on the mutagenicity of internal combustion engine exhaust fumes from diesel and diesel-soybean oil mixed fuels. In: ShortTerm Bioassay in the Analysis of Complex Environmental Mixtures III. pp. 191-214. Waters, Sandhu, Lewtas, Claxton, Chernolf and Nesnow, Eds., Plenum Press, New York.

Ma, T. H., Neas, R. E., Harris, M. M., Xu, Z., Cook, C., and Swofford, D., 1987. In vivo tests (Tra descantia- and mouse-micronucleus) and chemical analyses on drinking water of rural communities. In: Short-Term Bioassays in the Analysis of Complex Envirommenul Mixtures $V$. pp. 189-205. Sandhu, S. S., DeMarini, D. M., Mass, M. J., Moore, M. M. and Mumford, J. L., Eds., Plenum Press, New York.

Ma, T. H., Peng, Y., Chen, T. D., Sandhu, S. S., and Ruiz, E. F., 1989. Tradescantia-micronucleus (Trad-MCN) and Stamen Hair Mutation (TradSHM) assays on the clastogenicity of chemical mixtures and in situ monitoring of air and water pollution. Environ. Mol. Mutagen., 14 (Suppl. 15): 37

Ma, T. H., Sandhu, S. S., Peng, Y., Chen, T. I)., and Kim, T. W., 1992a. Synergistic and antagonistic effects on genotoxicity of chemicals commonly found in hazardous waste sites. Mutut. Res., 270: 71-77.

Ma, T. H., Snope, A. J., and Chang, T. Y., 1971. Far-red light effect on ultraviolet light induced chromatid aberrations in pollen tubes of Tradescantia. Radiat. Bot., 11: 39-43.

Ma, T. H., Sparrow, A. H., Schairer, L. A. and Nauman, A. F. 1978. Effect of 1,2-dibromoethane (DBE) on meiotic chromosomes of Tradescantia. Mutat. Res., 58: 251-258. 
Ma, 1. H, and Wolfi, S. 1965. Far-red-induced - mitotic delay and the apparent increase of Xray induced claromatid aberrations in Tradesrantia microspores. Radiat. Bot., 5: 293-298.

Ma, T. 11., Xu, C., L iao, S., and Jeong, 13. S., 1993a. Genotoxicity of landfill gaseous emission and leachates delected by Tradescantia plant bioassays, ln Ecotoxicology and Environmental (Kemisurv - A cilobal Perspestive. pp. 304. Sociely of Environmental Toxicology and Chemistry, Lisbon, Portugal.

Ma, 1. H., Xu, C., Liao, S., Jeong, B. S., and Leatherwood, R., 1993b. In situ monitoring of gaseous emission from a municipal incinerator using Tradescantia micronucleus and Tradescantia stamen hair mutation bioassays, In Ecotoxicology and Environmental Chemistry - A Global Perspective. pp. 304. Society of Envirommental Toxicology and Chemistry, I isbon, Porlugal.

Ma, T. H., Xu, C., Liao, S., McConnell, H., Jeong, B. S., and Won, C. D., 1996. In situ monitoring with the Tradescantia bioassays on the genoIoxicity of gaseous emissions from a closed fandlill site and an incinerator. Mutat. Res., 359: $39-52$.

Ma, T. H., Xu, C., Powers, L., and Liao, S., 1992b. In situ monitoring of clastogenicity of the gaseous agents emilled from a closed municipal waste site and from the incinerator with Tradescantia bioassays. Environ. Mol. Matagen., 19 (suppl. 20): 37

Ma, T. H., Xu, C., Powers, I.., Liao, S., and Knasmuller, S., 1992c. The Tradescantia-micronucleus test on the genotuxicity of leachates from a waste site and the suriace water of various sources. Environ. Mol. Mutagen., 19 (suppl. 20): 37 .

Ma, T. II., Xu, J., Xia, W., Jong, X., Sun, W., and Lin, (j., 1992d. Proficiency of the Tradescantia micronucleus image analysis system for scoring micronucleus frequencies and data analysis. Mutat. Res., 270: $39-44$

Marimuthu, K. M., Schairer, L. A., Sparrow, A. H., and Nawrocky, M. M., 1972. Effects of space flight (Biosatellite 11 ) and radiation on female gamelophyte development in Tradescantia. Am. J. Bot., 59: 359-366.
Mericle, L. W. and Mericle, R. P., 1967. Mechanism of somatic mulation for flowers of hybrid Tradescantia (clone (2). Genetics, 56: 576577.

Mericle, I. W. and Mericle, R. P., 1971. Somatic mutations in clone (12 Tradescantia: a search for genetic identity. I. Hered., 62: 323-328.

Mohammad, K. and Ma, T. H., 1983. Tradescantiamicronucleus (Trad-MCN) and TradescantiaStamen Hair (Trad-SHM) tests on common pesticides. Environ. Mol. Mutagen., 5: 370371 .

Natuman, C. H., Klotz, P. J. and Schairer, I. A., 1979. Uptake of tritiated 1,2-dibromoethane by Tradescantia floral tissues: relation to induced mutation frequency in stamen hair cells. Environ. Health Persp., 19: 201-215.

Nauman, C. H., Schairer, L. A., Sautkulis, R, C., and Klug, E. E. 1977a. Influence of hyperthermia on the spontaneous, radiation- and chemical-induced mutation frequency in Tradescantia stamen hairs. Radiat. Bot., 70: 632.

Nauman, C. H., Schairer, L. A. and Sparrow, A. H., 1977b. Influence of temperature on spontaneous and radiation-induced somatic mutation in Tradescantia stamen hairs. Mutat. Res., 50: $207-218$

Nauman, C. H., Sparrow, A. H. and Schairer, L. A. 1976. Comparative effects of ionizing radiation and two gaseous chemical mutagens on somatic mutation induction in one mulable and two non-mutable clones of Tradescantia. Mutat. Res., 38: 53-70.

Nauman, C. H., Sparrow, A. H., and Schairer, L. A., 1977c. Low dose mutation response relattionships in Tradescantia: Principle and comparison to mutagenesis following low dose gaseous chemical mutagen exposures, In Radiobiological Protection, First European Symposium on Rad-equivalence. EUR 5725e: pp. 13 23. Commission of the European Community, Luxembourg.

Nauman, C. H., Sparrow, A. H., Schairer, L. A. and Klug, E. E. 1974. Comparative effects of ionizing radiation and gaseous chemical mutagens on mutation induction in a mutable clone of Tradescantia. Radiat. Res. 59: 153-154. 
Nauman, C. H., Underbrink, A. G. and Sparrow. A. H. 1975. Influence of radiation dose rate on somatic mutation induction in Tradescantia stamen hairs. Radiat. Res. 62: 79-96.

Nayar, G. G., George, K. P. and Gopal-Ayengar, A. R. 1970. On the biological effects of high background radioactivity: studies on Tradescantia grown in radioactive monazite sand. Radiat. Bot., 10: 287-292.

Nayar, G. G. and Sparrow, A. H. 1967. Radiationinduced somatic mutations and the loss of reproductive integrity in Tradescantia stamen hairs. Radiat. Bot., 7: 257-267.

Peng, Y. and Ma, T. H., 1990. Tradescantia sisterchromatid-exchange (SCE) bioassay for environmental mutagens. In: Plants for Toxicity Assessment, ASTM STP 1091. pp. 319-323. Wang, W., Gorsuch, J. W., and Lower, W. R., Eds., American Society for Testing and Materials, Philadelphia.

Rodrigues, G. S., 1995. Assessment of the Abatement of Pesticide Mutagenesis in Situ by a Corn/Soybean Integrated Pest Management Program, Ph.D. Dissertation, Cornell University, Ithaca, NY.

Rodrigues, G. S., Madkour, S. A. and Weinstein, L. H. 1996. Genotoxic activity of ozone in Tradescantia. Environ. Exp. Bot., 36: 45-50.

Ruiz, E. F., Rabago, V. E. R, and Ma, T. H., 1987. Presencia de agentes genetoxicos en aguas residuales empleadas para riego utilizando el sistema de micronucleos en cellulas gameticas de Tradescantia clone 4430. In: III Semana dela Ecologia y Proteccion del Ambiente. 50: pp. 198. Universidad Autonoma de Queretaro, Mexico.

Ruiz, E. F., Rabago, V. M. E., Lecona, S. U., Perez, A. B., and Ma, T. H., 1992. Tradescantia micronucleus (Trad-MCN) bioassay on clastogenicity of wastewater and in situ monitoring. Mutat. Res., 270: 45-51.

Rushton, P. S., 1969. The effects of 5-fluorodeoxyuridine on radiation-induced chromatid aberrations in Tradescantia microspores. Radiat. Res., 38: $404-413$.

Sakamoto, E. T. and Takahashi, C. S., 1981. Action of benlate fungicide on Tradescantia stamen hairs and Allium cepa root-tip cells. Rev. Brasil. Genet., 4: 367-381.
Sanda-Kamigawara, M. and Ichikawa, S. 1993. Identity of normal and mutant flower-color pigments in four different Tradescantia clones confirmed by means of microespectrophotometry. Jpn. J. Genet., 68: 137.

Sanda-Kamigawara, M., Ichikawa, S., and Watanabe, K., 1991. Spontaneous, radiation- and EMSinduced somatic pink mutation frequencies in the stamen hair and petals of a diploid clone of Tradescantia, KU 27. Environ. Exp. Bot., 31: 413-421.

Sandhu, S. S., de Serres, F. J., Gopalan, H. N. B., Grant, W. R., Veleminsky, J., and Becking. G. C., 1994a. Environmental monitoring for genotoxicity with plant systems: an introduction and study design. Mutat. Res., 310: 169-173.

Sandhu, S. S., De-Serres, F. J., Gopalan, H. N. B., Grant, W. R., Svendsgaard, D., Veleminsky, J., and Becking, G. C., 1994b. Environmental monitoring for genotoxicity with plant systems: results and recommendations. Murat. Res., 310: 257-263.

Sandhu, S. S., Ma, T. H., Peng, Y., and Zhou, X., 1989. Clastogenicity evaluation of seven chemicals commonly found at hazardous industrial waste sites. Mutat. Res., 224: 437-446.

Sax, K., 1938. Chromosome aberrations induced by X-rays. Genetics, 23: 494-516.

Sax, K. and Edmonds, H. W., 1933. Development of the male gametophyte in Tradescantia. Bot. Gaz., 95: 156-163.

Schaeffer, D. J., Novak, E. W., Lower, W. R., Yanders, A., Kapila, S., and Wang, R., 1987. Effects of chemical smokes on flora and fauna under field and laboratory exposures. Ecotox. Environ. Saf., 13: 301-315.

Schairer, L. A., 1979. Mutagenicity of ambient air at selected sites in the United States using Tradescaniia as a monitor. In: In Situ Toxicity Testing of Environmental Agents. Current and Future Possibilities - Part A: Survey of Test Systems. pp. 167-190. Kolber, T. K., Grant, L. D., DeWoskin, R. S., and Hughes, T. J., Eds., Plenum Press, New York.

Schairer, L. A. and Sautkulis, R. C. 1982. Detection of ambient levels of mutagenic atmospheric pollutants with the higher plant Tradescantia. In: Envirommental Mutagenesis, Carcinogene- 
sis, and Plant Biology. pp. 155-194. Klekowski, E. J., Jr., Ed., Praeger, New York.

Schairer, L. A., Sautkulis, R. C., and Tempel, N. R., 1982. Monitoring ambient air for mutagenicity using the higher plant Tradescantia. In: Genotoxic Effects of Airborne Agents. Environmenlal Science Research. pp. 123-140. Tice, R. R., Costa, D. L., and Schaich, K. M., Eds., Plenum Press, New York.

Schairer, L. A., Van't Hof, J., Hayes, C. C., Burton, M. R., and de Serres, F. J., 1979. Measurement of biological activity of ambient air mixtures using a mobile laboratory for in situ exposure, preliminary results from the Tradescantia plant lest system. In: Application of Short-term Bioassays in the Fractionation and Analysis of Complex Environmental Mixtures. pp. 419-440. Waters, M., Nesnow, Huisingh, Sandhu, S. S., and Claxton, Eds., Plenum Press, New York.

Schairer, L. A., Van't Hof, J., Hayes, C. C., Burton, R. M., and de Serres, F. J., 1983. Exploratory monitoring of air pollutants for genotoxicity activity with Tradescantia stamen hair system. Environ. Health Persp., 27: 51-60.

Sharma, C. B. S. R. and Panneerselvan, N., 1990. Genetic toxicology of pesticides in higher plant systems. Crit. Rev. Pl. Sci., 9: 409-442.

Shima, N. and Ichikawa, S., 1994. Synergism detected among methyl methanesulfonate, ethyl methanesulfonale and $X$-rays in inducing somatic mutations in the stamen hairs of Tradescantia clone BNL 4430. Environ. Exp. Bot., 34: 393408 .

Shima, N. and Ichikawa, S., 1995a. Detection of synergism among different monofunctional alkylating agents with the stamen-hair system of Tradescantia clone BNL 4430. Jpn. J. Genet., 70: 724 .

Shima, N. and Ichikawa, S. 1995b. Mutagenic synergism detected between dimethyl sulfate and $\mathrm{X}$-rays but not found between $N$-methyl- $N$ nitrosourea and $X$-rays in the stamen hairs of Tradescantia clone BNL 4430. Mutat. Res., 331: 79-87.

Smith, S. S. and Lofty, T. A., 1954. Comparative effects of certain chemicals on Tradescantia chromosomes as observed at pollen tube mitosis. Amer. J. Bot,. 41: 589-593.
Sparrow, A. H. and Ichikawa, S., 1967. Comparison of radiation-induced loss of reproductive integrity in the stamen hairs of a polyploid series in Tradescantia. Radiat. Res., 31: 636.

Sparrow, A. H. and Schairer, L. A., 1971. Mutational response in Tradescantia after accidental exposure to a chemical mutagen. EMS Newsletter, 5: $16-19$.

Sparrow, A. H. and Schairer, L. A., 1974. The effects of chemical mutagens (EMS, DBE) and specific air pollutants $\left(\mathrm{O}_{3}, \mathrm{SO}_{2}, \mathrm{NO}_{2}, \mathrm{~N}_{2} \mathrm{O}\right)$ on somatic mutation rate in Tradescantia. In: Geneticheskie Poaledstviya Zagryazneniya Okruzhayuschchei Sredy (Genetic Effects of Pollution in the Environment). pp. 50-61. Bubinin, N. P., Eds., Institute Obshchei Genetiki, Moscow.

Sparrow, A. H., Schairer, L. A., and Marimuthu, K. M., 1968. Genetic and cytologic studies of Tradescantia irradiated during orbital flight. BioSci., 18: 582-590.

Sparrow, A. H., Schairer, L. A., and Villalobos, R., 1973. Comparison of somatic mutation rates induced in Tradescantia by chemical and physical mutagens. Mutat. Res., 21: 238-239.

Sparrow, A. H. and Singleton, W. R, 1953. The use of radiocobalt as a source of gamma rays and some effects of chronic irradiation on growing plants. Amer. Nat., 87: 2948.

Sparrow, A. H. and Sparrow, R. C., 1976. Spontaneous somatic mutation frequencies for flower color in several Tradescantia species and hybrids. Environ. Exp. Bot., 16: 23-43.

Sparrow, A. H., Underbrink, A. G., and Rossi, H. H., 1972. Mutations induced in Tradescantia by small doses of X-rays and neutrons: analysis of dose-response curves. Science, 176: 916 918.

Steffensen, D., 1953. Induction of chromosome breakage at meiosis by a magnesium deficiency in Tradescantia. Proc. Natl. Acad. Sci. U.S.A., 39: $613-620$.

Steffensen, D., 1954. Irregularities of chromosome divisions in Tradescantia grown on low sulfate. Exp. Cell Res., 6: 554-556.

Steffensen, D., 1955. Breakage of chromosomes in Tradescantia with calcium deficiency. Proc. Natl. Acad. Sci. U.S.A., 41: 155-160 
Steinitz, L. M., 1944. The effect of lack of oxygen on meiosis in Tradescamia. Amer. J. Bol., 31 : $428-443$.

Tano, S., 1987. Induced somatic mutations by radia tion and chemicals in Tradescantia. Mutat. Res.. 181: 209-214.

Tano, S. 1989. In sifu detection of induced muta tions with chemicals by Tradescantia. Environ. Mol. Mutagen., 14 (Suppl. 15): 197.

Tano, S., 1990. In situ detection of induced mutations with chemicals by Tradescantia. In: Muta tion and the Environment. Progress in Clinical and Biological Research. pp. 57-66. Mendelsohn, M. L. and Albertini, R. J., Eds., Wiley-Liss, New York.

Tano, S. and Yamaguchi, H., 1979. Effects of low dose irradiation from 131 on the induction of somatic mutations in Tradescantia. Radiat. Res., 80: $549-555$

Tano, S. and Yamanguchi, H., 1985. Effects of several nitroso compounds on the induction of somatic mutations in Tradescantia with special regard to the dose response and threshold dose. Mutat. Res., 148: 59-64.

Tano, S., Yamaguchi, H. and Ueda, S. 1984. Effects of low dose tritium labeled thymidine and uridine on the induction of somatic mutations in Tradescantia. Environ. Exp. Bot., 24: 173177.

Taylor. J. H., 1950. The duration of differentiation in excised anthers. Am. J. Bot., 37: 137-143.

Tomkins, D. J. and Grant, W. F., 1972. Comparative cytological effects of the pesticides menazon, metobromuron and tetrachloroisophthalonitrile in Horderm and Tradescantia. Cam. J. Genet. Cytol., 14: 245-256.

Underbrink, A. G., Chairer, I. A., and Sperrow, A. H., 1973a. The biological properties of $3.9-\mathrm{GeV}$ nitrogen ions $\mathrm{V}$. Determination of relative biological effectiveness for somatic mutations in Tradescomiar. Radiat. Res. 55: 437-444.

Underbrink, A. G., Lower. W. R., Yanders, A. F., and Ranney, T. K., 1984. New methodology for assessing the toxicity of water and related sediments. In: 18th Anmul Conference on Trace Substances in Environmental Heallh. pp. 351 355. University of Missouri.
Underbrink, A. G., Schairer, L. A., and Sparrow A. H., 1973b. Tradescantia stamen hairs: a radiobiological test system applicable to chemi cal mutagenesis. In: Chemical Muragens Principles and Methods for Their Detection. pp. 171-207. Hollaender, A., Ed., Plenum I'ress, New York.

Underbrink, A. G., Schairer, L. A., Sparrow, A. H. and Rossi, H. H., 1971. Relative biological ef fectiveness of 0.43-Mev and lower energy neutrons on somatic aberrations and hair length in Tradescantia stamen hairs. Int. I. Rediat. Biol., 19: $215-228$.

Underbrink, A. G. and Sparrow, А. H., 1974. The influence of experimental endpoints, dose, dose rate, neutron energy. nitrogen ions, hypoxia, chromosome volume and ploidy level on RBF in Tradescantia stamen hairs and pollen. In: Biological Effects of Neuron Irradiation. pp. 185 214. International Atomic Energy Agency. Vienna.

Underbrink, A. (j., Sparrow, A. H., Sautkulis, I). and Mills, R. E., 1975a. An elusive lactor affect. ing mutation frequency in Tradescamtia stamen hairs: its influence on RBE. III. I. Radiat. Biol., 28: 527-538.

Underbrink, A. G., Sparrow, A. H., Sautkulis, D., and Mills, R. E., 1975b. Oxygen enhancement ratios (OERs) for somatic mutations in Tra descantia stamen hairs. Radiat. Bot., 15: 161 168.

Van't Hof, J. and Schairer, L. A., 1982. 7radescantia assay system for gaseous mutagens. A report of the U.S. Environmental Protection Agency Gene-Tox Program. Mutat. Res., 99: 30) $3-315$.

Veleminsky, J., Briza, J., and Gichner, 'T., 1987. Benzamide increases the frequency of mutations induced by $\mathrm{N}$-methyl-N-nitrosourea in higher plants: Tradescantia, Nicotiana tabasm and Ambidepsis thaliana. Biol. Zhl., 106: 67-71.

Veleminsky, J. and Gichner, T., 1988. Mulagenic activity of promutagens in plants: indirect evidence of their activation. Mutat. Res., 197: $221-242$.

Villalobos-Pietrini, R., Hemandes, R., Guadarrama, M. d. I. A., and Gomez-Arroyo, S., 1986. Cytological detection of somatic mutations in Tra- 
descantia induced by ethanol. Cytology, 51: 211-218.

Waters, M. D., Stack, H. F., and Brady, A. L., 1987. Genelic activity profiles of some chemicals found in hazardous wastes. Internal Report, Health Effects Research Laboratory, Genetic Toxicology Division, PB88-107537/XAB.

Xiao, L, Z. and Ichikawa, S., 1995. Mutagenic interactions between maleic hydrazide and $X$-rays in the stamen hairs of Tradescantia clone BNL. 4430. Jpn. J. Genet., 70: 473.

Xiao, L. Z. and Ichikawa, S., 1996. Peroxidase activities in the lloral tissues of Tradescantia clone BNL 4430 treated with maleic hydrazide alone, X-rays alone, or in combinations. Genes Genet. Syst., 71: 151.
Xu, J., Ma, T. H., Xia, W., Jong, X., and Sun, W., 1989. Image analysis system for rapid data processing in Tradescantia-micronucleus bioassay. In: Plants for Toxicity Assessment. pp. 346-356. Wang, W., Gorsuch, J. W., and Lower, W. R., Eds., American Society for Testing and Materials, ASTM STP 1091, Philadelphia, PA.

Zhang, H., Ma, 'T. H., Jeong, B. S., and Won, C. D., 1994. Antimutagenic property of a Chinese herb, Polygonum multiflortum Thunb. Environ. Mol. Mutagen. 23 (Suppl. 23): 76.

Zheng, D., 1985. Tradescantia-micronucleus tests on the industrial wastewater from a printing and dying factory in Fuzhou city. J. Fujian No. Uni., 21: 5-7. 